\title{
History and Exegesis in the Itinerarium of Bernard the Monk (c. 867)
}

\section{Daniel Reynolds*}

This article presents a re-evaluation of the ninth-century Itinerarium Bernardi monachi franci, which describes the journey of the monk Bernard to Jerusalem and the Holy Places. Challenging traditional perceptions of the work, as a straightforward narrative of travel, this article argues that a more contextual reading of the source and its topography, with respect to ninth-century exegetical and liturgical culture, identifies the Itinerarium as a text closely linked to exegetical explorations of the themes of penitence and just rule. It concludes that an examination of the motifs of the Old Testament world kingdoms and themes of Christian triumph within the work identifies Bernard as a writer engaged in an attempt to incorporate the world of Islam within a Christian salvific worldview and the eventual promise of redemption.

Keywords: Jerusalem; Pilgrimage; Islam; Abbasid; Exegesis; Carolingian; Bernard the Monk

Bernard the Monk hides from medievalists in plain sight. Although often integral to recent reconstructions of early medieval pilgrimage routes, or broader appraisals of ninth-century Mediterranean exchange, targeted analysis of the Itinerarium Bernardi monachi franci remains a notable critical blind spot in studies of ninth-century literary culture. ${ }^{1}$ To some extent, this dearth of interest is unsurprising. Due to its uniqueness as an example of a ninth-century "Holy Land ${ }^{2}$ itinerarium, Bernard's text lacks a related corpus of comparable writings that would provoke more widespread interest in the source as a component of a defined literary "genre«. Equally, as a relatively simple composition, the Itinerary does not display many of the literary and intellectual qualities of other ninth-century works that have

* Correspondence details: Dr. Daniel Reynolds, Centre for Byzantine, Ottoman and Modern Greek Studies, School of History and Cultures, 3rd Floor, Arts Building, University of Birmingham, Birmingham B15 2TT, UK; email: d.k.reynolds@bham.ac.uk.

1 The major critical study of the text and its transmission remains Ackermann, Itinerarium. References to the text are based on this edition. Translated extracts are taken from Dutton, Carolingian Civilization, 472-479, with some amendments based on the Ackermann edition (noted in the footnotes). Throughout this article I will refer to the text by the English term "Itinerary". In the interests of clarity, I will continue to refer to the author of the piece as »Bernard«.

2 "Holy Land « is a complex and amorphous term which already by the ninth century was beginning to reveal considerable differences between Christian writers in Byzantium and the West regarding its extent and the places it included. For the purposes of this article, »Holy Land « will refer to the landscape associated with the events of the Bible and Gospel, which roughly spans the modern regions of Israel and the Palestinian Territories and Jordan. 
attracted more forensic commentary and academic interest since the late nineteenth century. ${ }^{3}$ Indeed, critical approaches to the Itinerary have generally deviated little from a basic observation of the text as a straightforward narrative of travel and have yet to apply the lessons gained from more successful critical re-readings of medieval pilgrimage itineraria that have surfaced over the past two decades. ${ }^{4}$

The recent appearance of the critical edition and commentary of the Itinerary by Josef Ackermann, however, makes a reassessment of Bernard's text in light of its contemporary intellectual milieu both pertinent and timely. ${ }^{5}$ Ackermann's commentary has done more than any other study to establish a later ninth-century date for the text and broadly locate its composition within the territories of the Frankish kingdoms in the third quarter of the ninth century. ${ }^{6}$ Based on the Itinerary's explicit reference to the reign of Louis II (king of Italy 840, Carolingian emperor 855-875; whom Bernard describes as living), the pontificate of Nicholas I (858-November 867) and the patriarchal reigns of Theodosios of Jerusalem (864-879) and Michael of Alexandria (860-870), Ackermann, has firmly advocated a date of c. 867 as the most plausible for Bernard's journey. ${ }^{7}$ In connection with these observations, Ackermann has noted that the Itinerary's positive perception of Louis II and his mediation of the dispute between Radelchis and Siconulf (848), lends some tentative support to the identification of Bernard as a writer broadly aware of political developments within Italy and the Frankish world shortly before the capture of Bari in $871 .^{8}$ Based upon this evidence, Ackermann has proposed a date range of c. 867 -c. 871 as the most plausible for the composition of the work.

Attempts to reappraise the text in light of Ackermann's key observations and dating have, nevertheless, proven slow to emerge, a situation that owes much to the continued anonymity of Bernard as a writer and the uniqueness of his work as an example of a ninth-century Holy Land itinerary. Consequently, Bernard's work continues to be seen as an essentially straight-

3 The literature on this subject is immense and continues to grow annually. Therefore, I direct the reader to the major studies and their accompanying bibliographies, Bullough, Roman books and Carolingian renovatio; Contreni, Carolingian renaissance; Godman, Poets and Emperors, McKitterick, Carolingians and the Written Word; McKitterick, Books, Scribes and Learning; McKitterick, History and Memory; Nelson, Kingship, law and liturgy; Nelson, Literacy in Carolingian government; Stratmann, Hinkmar von Reims.

4 Bowman, History's Redemption, 163-187; Elsner, Itinerarium Burdigalense, 181-195; O'Loughlin, Exegetical purpose, 37-53; O'Loughlin, Adomnán and the Holy Places. Halevi, Bernard, explorer, 24-50, especially 45-48, and Ackermann, Itinerarium, 72-93.

5 Ackermann, Itinerarium, 1-112.

6 Ackermann, Itinerarium, 30-55.

7 Ackermann, Itinerarium, 51-54. William of Malmesbury, who had access to a copy in the 1120s, dated the journey to 870, William of Malmesbury, William of Malmesbury, Gesta Regum Anglorum, IV. 376.3-386.4, ed. and trans. Mynors, 642-657. On the pontificate of Nicholas I, including regnal dates, see Norwood, Political pretensions, 271-285. See also Liber Pontificalis, ed. Duchesne 107.1, 107.83, trans. Davis, 205, 247 and critical discussion, 189-204. Itinerary, 24. On the dates for the Patriarch Theodosios and Michael, Sa id ibn Batriq, Nazm al-Jawhar, ed. Cheikho, 153-154, 183-184, trans. Pirone, 413-418. These are confirmed by a series of surviving letters from Dawud, Metropolitan of Damascus concerning his dispute with the Patriarch of Antioch. These are preserved in MS Milan, Ambrosiana, X 201 supp., fols 94r-137v. An edition is currently under preparation by John Lamoreaux and Abdul-Massih Saadi. For a brief introduction, see Lamoreaux, David of Damascus, 79-82. I wish to express my gratitude to Prof. John Lamoreaux for sharing his unpublished translation of this text. A general overview of the period may be found in Kreutz, Before the Normans, 23 and also the important studies by Berto, Erchempert, a Reluctant Fustigator, 147-175 and Berto, Remembering, 23-53.

8 Ackermann, Itinerarium, 98-103. 
forward geographical description of the ninth-century Holy Land, interspersed with scriptural elements, rather than a text that, from its inception, was composed with clear reference to a typological understanding of Jerusalem's landscape drawn from established exegetical models.

Regardless of whether or not we consider Bernard's Itinerary to be an account of a »real« ninth-century journey, or Bernard as an individual who actually lived, such a positivist reading of the Itinerarium Bernardi monachi Franci is fundamentally misplaced. Although several of the details offered by the Itinerary disclose Bernard's awareness of contemporary developments within Carolingian territory and Italy during the 860s, these are often situated within a wider framework that stresses the typological significance of these events and places as part of a broader Christian understanding of time and revelation. Rather than peripheral to a reading of the narrative, these typological motifs are central to the interpretation and recognition of the Itinerary as an under-appreciated exegetical work, informed by ninth-century liturgical experience and understanding of biblical time.

This study aims to situate the topography of the Itinerary within the context of biblical exegesis in the late 860 s and to demonstrate how Bernard fashioned the Itinerary as an exegetical exploration that responded to an increasing emphasis on the physicality of Christ's Passion and final hours within ninth-century liturgical experience. As a product of the late ninth century, the Itinerary is also structured around a number of themes that situate Bernard's experiences of Muslim hegemony in the Holy Land within a broader Christian understanding of time and revelation.

In order to appreciate these aspects of the text, however, it is also necessary to briefly address the legacy of the more positivist readings of Bernard's text that have emerged since the late nineteenth century, many of which have their origins in early modern conventions of textual criticism and translation. ${ }^{9}$ This study, therefore, will begin with a review of this history of publication before proceeding to address the primary themes and topography of Bernard and situate them within the wider intellectual and exegetical context of its former ninth-century milieu.

\section{Publication and Legacy}

To begin, I want to set aside the impossible question of whether Bernard the monk ever lived, or if the journey to Jerusalem described by the Itinerary ever took place. As the following discussion will explore, Bernard's use of existing literary models in his description of Egypt and the Holy Land, many of which resonate with themes addressed by other writers active during the mid-ninth century, leads me to doubt the usefulness of the Itinerary as an account from which we could construct meaningful information about the ninth-century Holy Land and Egypt. That Bernard was aware of several key historical developments in Italy and the Caliphate in the period c. 848-c. 871 is clear from a number of episodes in the Itinerary, including his allusion to the arbitration of Louis II between Radelchis and Siconulf and his description of the Emirate of Bari shortly before its capture in $871 .{ }^{10}$ Nevertheless, these vignettes often unfold against a literary topography that was evidently constructed to stress the typological importance of the landscape that the journey follows - especially as Bernard's journey moves beyond Italy and enters Egypt and the Holy Land. 
For convenience I will continue to refer to the author as Bernard and talk about his journey as one that took place, albeit with the caveat that neither of these things is certain or intrinsic to the interpretation presented here, nor possible to prove from the details that the Itinerary presents internally. As a unique text, written by an otherwise unknown historical figure, the Itinerarium Bernardi monachi Franci is a self-contained source that effectively exists in isolation. The existence of Bernard cannot be verified by an independent witness, nor does the text appear to have generated wider interest in the biography of its writer among later medieval commentators. Everything that is known about the Itinerary, including the identity of its author and protagonist, must be extracted from the internal thought-world that the narrative presents. ${ }^{11}$ In this respect, the premise of the Itinerary as an actual journey is, at face value, a convincing one. According to the account, in the late 860s, a monk named Bernard embarked on a journey from Rome to Jerusalem accompanied by two monastic companions named Stephen of San Vincenzo and Theudemund the Spaniard. ${ }^{12}$ Beginning his journey at Rome, Bernard passed through Italy, first reaching the shrine of St Michael at Monte Gargano, before proceeding to Bari and the port of Taranto. After crossing the Mediterranean Sea on a slave ship, the Itinerary describes Bernard's arrival in Alexandria and his passage down the Nile to Babylon of Egypt (al-Fustat), where he was imprisoned for six days. The Itinerary then proceeds to describe Bernard's journey eastwards to Sitinuth (Sitinulh), Maalla (Maalla), and Damietta (Amiamatem) before his arrival at Tinnis (Tamnis) and Farama (Farameam), from where he entered the Holy Land. Journeying through the desert, Bernard and his companions then reached Gaza, before turning eastwards to Ramla (Ramulam), the shrine of St George, Emmaus (Emaus) and finally, Jerusalem, itself. Having described Bernard's visit to the Sepulchre and Mount Sion, the Itinerary then proceeds to describe the churches in the Valley of Jehoshaphat, the Mount of Olives and Bethany (Bathaniam), before describing Bernard's experiences in Bethlehem (Bethleem) and at the River Jordan. Returning by sea, Bernard and his companions travelled for sixty days, disembarking at Mons Aureus (San Michele in Olevano sul Tusciano) before reaching Rome and travelling to complete his journey at Mont-Saint-Michel in Normandy. ${ }^{13}$ At some point after his return, but apparently before the death of Louis II in 875, Bernard purportedly compiled a description of his journey which is known today by the Latin title Itinerarium Bernardi monachi francithe only text of its type to survive from the ninth century.

Throughout the text are further details of Bernard's experiences during his travels through Egypt. Bernard, for example, describes the permits that he was required to solicit from the papacy and Muslim authorities for permission to travel. ${ }^{14}$ Names of reigning Muslim governors (Suldanus, Amarmoni and Adelacham) and references to slavery, Christian taxation and Bernard's own imprisonment in "Babylon" (al-Fustat), further add to the impression of the Itinerary as an account of a lived experience in real space. ${ }^{15}$

11 The possibility that Bernard is an authorial device, rather than an actual historical figure, remains possible, but ultimately unprovable. Thomas O'Loughlin's study has proposed that Arculf is an authorial device of Adomnán O’Loughlin, Adomnán and Arculf, 127-146. Alternative readings are suggested by Woods, Arculf's luggage, 25-52 and Hoyland and Waidler, Adomnán's De Locis Sanctis, 787-807. 
It is these particular details that have firmly ensconced the Itinerary within broader studies of early medieval pilgrimage and early Islamic Jerusalem. ${ }^{16}$ Yet, despite its renown, it is important to note that Bernard's Itinerary shapes perceptions of ninth-century Jerusalem and Egypt for a wider audience today than it could possibly have achieved at the point of its composition and in succeeding centuries. Although known to writers by the 1120s, the text was not widely copied in later centuries and lacked the popularity of the better-known descriptions of the Holy Land compiled by Adomnàn of Iona and Bede. ${ }^{17}$ It was not until the publication of a version drawn from a manuscript preserved in Reims by Jean Mabillon in 1672, which appeared in the Patrologia Latina, and the slightly later edition of Titus Tobler in 1874 , that the text became more widely known to scholarly audiences and secured its position within the canon of "pilgrim literature « ${ }^{18}$ Translations of the text into English, first by the Palestine Pilgrims' Text Society in 1893 and later in John Wilkinson's seminal study of 1977 (and its 2002 re-edition), Jerusalem Pilgrims before the Crusades, have resulted in further dissemination of this text and its use in studies of the Pre-Crusader Holy Land. ${ }^{19}$

Critical approaches to the Itinerary have, for the most part, continued to operate within the interpretative parameters established by Titus Tobler's 1874 edition. Though accessible, Tobler's reproduction of the text is problematic for the way in which it situated Bernard's narrative alongside other similar descriptions of the Holy Land, none of which are known to have circulated together until the nineteenth century. ${ }^{20}$ Modern appraisal of Bernard's work, therefore, generally approaches the Itinerary as part of a compendium of descriptions of the Holy Land, variously dated between the seventh and eleventh centuries, which may be analysed and cross-referenced in a manner that evokes the methodology of early modern Biblical concordance. Thus, the topographies presented in one text are compared and overlapped with the descriptions contained within another and used to make broader assessments of the shifting contours of the Holy Land and the survival of its churches in the Early Islamic period. ${ }^{21}$

16 Leor Halevi's 1998 study, for example, draws together the internal details of the Itinerary to emphasise the difficulties Bernard faced in negotiating his journey through Muslim lands, Halevi, »Bernard«, 24-50. Michael McCormick's pivotal Origins of the European Economy follows suit in utilising Bernard's text as a source for reconstructing ninth-century Mediterranean exchange, McCormick, Origins of the European Economy, 134-138. Recent studies of medieval slavery, pilgrimage and Christian-Muslim interactions also remain indebted to the Itinerary's internal details, see McCormick, New Light on the »Dark Ages«, 17-54; Bruce, Cluny and the Muslims, 22.

17 O'Loughlin, Diffusion, 93-106.

18 Bernardus Monachus Francus, Bernardi Itinerarium, ed. Migne, 569-574, which was taken from a fourteenth century manuscript. This manuscript was first published by Jean Mabillion in the Acta SS. Ord S. Bend. Tom IV, in 1672: Mabillon Bernardi monarchi Franci aliud Itinerarium, Mabillon, 523-526. For Titus Tobler's edition see Bernardi Itinerarium (Tobler), 86-99.

19 Bernard, Library; Wilkinson, Jerusalem Pilgrims, 141-145, Wilkinson, Jerusalem Pilgrims (second edition), 261-269. Wright, Early Travels in Palestine, 23-31.

20 This includes Hugeberc's Vita Willibali and John of Wurzburg's Descriptio terrae sancta, Tobler, Descriptiones Terrae Sancta, 1-312.

21 Key examples of this approach are Aist, Christian Topography; McCormick, Charlemagne's Survey, 81-88. 
Archaeological appraisals of early Islamic Jerusalem have proven particularly susceptible to this method, and it remains common to encounter chronologies of individual church sites whose existence beyond 700 is established through comparison of the texts preserved within the Tobler volumes and the related translations of John Wilkinson. ${ }^{22}$ Often, such chronologies have been established without full recognition that many of the sites mentioned in the Itinerary were excavated after the publication of Tobler's edition and have not escaped the influence of this text, and others in Tobler's volume, on the conclusions drawn by their excavators. Louis-Hugues Vincent's interventions at the Eleona Church on the Mount of Olives in 1911, for example, relied heavily upon Tobler's edition of the Itinerary to establish a ninth-century phase for the church, rather than through an examination of the material recovered during its excavation. ${ }^{23}$

Bernard's Itinerary may not be unique in this regard, but the relative anonymity of its author has deterred further interest in the language and style of the text, that in the examples of Adomnán, Bede and Hugeburc's Vita Willibali have provoked caution in the use within historical reconstructions of the early Islamic Holy Land. ${ }^{24}$ On occasion, this neglect has also obscured the identification of important scriptural parallels within the Itinerary that would likely have been as significant to its ninth-century readers as the description of the journey itself. Bernard's imprisonment in Egypt recounted in chapter 7 of the Itinerary, for example, which the Latin text renders as "donec post dies sex inito consilio, cum Dei auxilio" offers its readers an important typological parallel between the experiences of Bernard's six-day imprisonment in Babylon and that of the prophet Daniel that the text also draws in other passages. ${ }^{25}$

This is a single example among many, which requires a more detailed discussion beyond the scope of this article. But it is, nevertheless, an instructive point for what it reveals about the influence of the Book of Daniel as one of a number of typological subjects around which the Itinerary is structured. When examined closely, what they reveal is the extent to which Bernard closely modelled his descriptions of the Holy Land in response to a number of exegetical themes and concerns that were extant within Italy and the wider "Carolingian" cultural milieu at the time of the Itinerary's composition around the third quarter of the ninth century.

22 Key examples include the excavations of the Eleona Church on the Mount of Olives by Louis-Hugues Vincent and the Church of the Probatica, whose post-Byzantine chronologies draw heavily on the textual accounts that appear in the editions of Titus Tobler: Bouwen and Dauphin, Piscine probatique. This approach also frames the discussions and dating of Shalev-Hurvitz, Holy Sites Encircled, 143-167.

23 Vincent, Église, 219-65.

24 Adomnán, De locis sanctis, ed. Bieler, 183-234D; Bede, De locis sanctis, ed. Fraipoint, 244-280.

25 This parallel has often been overlooked in recent treatment of the text, often due to the influence of the popular translation by John Wilkinson over later studies. In the Wilkinson version the text donec post dies sex inito consilio, cum Dei auxilio is translated as "Then, with the help of God «, and omits the important parallel with Daniel 14.31, Itinerary, 7; Wilkinson, Jerusalem Pilgrims (second edition), 263. 


\section{Itinerarium Bernardi: Context and Transmission}

With respect to Bernard's Itinerary, what those particular concerns were, and the identity of the text's original audience, remain somewhat unclear. Unlike Adomnán or Bede, the meagre details related to Bernard's biography do not lend themselves to the kind of detailed contextual discussion of the Itinerary that can be achieved with these earlier and better-known works. ${ }^{26}$ The paucity of later references to the Itinerary and the lack of surviving ninthcentury copies of the text also complicates our ability to situate Bernard's writings within the context of a specific intellectual milieu, especially in view of Josef Ackerman's identification of the commonly-cited line from Tobler's edition of the Itinerary, "Francia vero est navitatis meae locus" ("Francia, truly, is the place of my birth«), as a later interpolation only present in the Reims manuscript. ${ }^{27}$ Ackermann's analysis of the lexicography and syntax of the Latin text has also failed to pinpoint Bernard's identity and place of activity with precision, although it broadly places Bernard's activity somewhere within the Carolingian political milieu in the period $867-871 .^{28}$

It is also clear that the Itinerary did not experience a level of dissemination comparable to the descriptions of the Holy Land attributed to Adomnán, Bede and Jerome, which continued to generate interest beyond $1100 .{ }^{29}$ Only six copies of Bernard's Itinerary have been identified and there are few indications that the text exerted significant influence over later perceptions of the Holy Land among writers active beyond $900 .{ }^{30}$ William of Malmesbury is the only later writer who indicates direct knowledge of Bernard's Itinerary. ${ }^{31}$ William, however, appears to have been unaware of his identity beyond his status as a monk, perhaps indicating that the text was already circulating as a purely textual unit by the 1120 s without further interest in the biography of its writer. ${ }^{32}$ All that we may say beyond this is that by the twelfth century the Itinerary was commonly encountered as part of a compendium of texts describing the Holy Land that were often bound in single volumes. ${ }^{33}$

26 O'Loughlin, Adomnán and the Holy Places; O'Loughlin, Library of Iona, 33-52; O’Loughlin, Exegetical, 37-53; O'Loughlin, De Locis Sanctis as a liturgical text, 181-192; O'Loughlin, Diffusion, 93-106. Bede, De locis sanctis, ed. Fraipoint, 244-280. This is attested in two ninth-century copies. Laon, Bibliothèque publique, 216, from Notre Dame, Laon; and Munich, Staatsbibliothek, 6389; see Laistner, Hand-list, 83-86.

Bede, Historia ecclesiastica. The literature on Bede is immense and beyond the scope of this study, I direct the reader to Brown, Companion.

27 Ackermann, Itinerarium, 4, 55-69, 115, 128.

28 Ackermann, Itinerarium, 4, 55-69, 115, 128.

29 Ackermann, Itinerarium, 9-19, who surveys the manuscript tradition of the surviving copies.

30 See MS Cotton, Faust. B. i. 192; Catal. Codd. MSS. Coll. Linc. Oxon. 46 (cod. xcvi. 118); Wright, Early Travels in Palestine, xvi. The Rheims manuscript underpins the edition published by Mabillion, Bernardi monachi Franci alius Itinerarium, 523-526, later printed as Bernardi Itinerarium, ed. Migne, col. 569-574. London, British Library, Cotton Faustina B1 ff.2-11; London, British Library, Cotton Vitellis E.11.Vienna, Österreichische Nationalbibliothek, 2432, fols.24v-28r. Oxford, Lincoln College, lat. 96, fols. 122r-127v and Oxford, Worcester College 285, fols. 252r-254v.

William of Malmesbury, Gesta Regum Anglorum, IV. 376.3-386.4, ed. and trans. Mynors, 642-657. William of Malmesbury, Gesta Regum Anglorum, IV. 376.3-386.4, ed. and trans. Mynors, 642-657. Bernard as Bernardi monachi. The evidence from the surviving copies indicates that by the twelfth century the Itinerary was commonly encountered as part of a compendium of texts describing the Holy Land that were often bound in single volumes, Ackermann, Itinerarium, 9-19.

33 Ackermann, Itinerarium, 9-19. 


\section{Bernard and his Sources}

Without further details, it is impossible to locate Bernard within the context of a specific ecclesiastical foundation or region. As a result, any attempt at a detailed exegetical reading of the work is hampered by our inability to know exactly which works Bernard had access to and from which scriptorium he was operating. As this discussion will explore, Bernard's use of several typologies and pericopes that had already been established by earlier writers well known to ninth-century audiences, including Ambrose, Augustine, Bede, Jerome and Isidore of Seville, lend support to an identification of Bernard as a figure well versed in the canon of Latin exegetical thought. Further, Bernard's interest in the scheme of the world kingdoms described in the Book of Daniel and his interest in biblical typologies associated with penance and just rule, resonate with the interests of several other Frankish writers active in the 860 s and suggests that we should broadly understand Bernard's topography as a product and response to this intellectual milieu, even if his origin and place within this intellectual landscape cannot be located with precision.

Bernard himself makes very little direct reference to his sources and, as a text, the Itinerary is often difficult to situate within the literary genre to which it has been traditionally ascribed. In one respect, the Itinerary employs the conventional structure of an itinerarium (and, indeed, identifies itself as one). ${ }^{34}$ Following its protagonist on a sequential journey across the landscape, the narrative introduces specific topographical markers that are briefly described to the reader. The journey of Bernard and his companions through Egypt, for example, is narrated in a series of stages that permit its readers to trace their movements from one point to another.

So these things being so, we returned back along the river Gion for three days and we came to the city of Sitimuth. From Sitimuth we progressed towards Maalla and from Maalla we crossed over to Damietta, which has the sea to the north, and apart from a small piece of land, is surrounded by the Nile. From there we sailed to the city of Tanis in which there are many devout, warm and hospitable Christians. Indeed there is nowhere in the land belonging to this city that does not possess a church, and wherein the field of Tanis is pointed out, where there are what appear to be three walls, which are the bodies of those who were born in the days of Moses. ${ }^{35}$

Despite these stylistic parallels with earlier itineraria, Bernard's text also departs from the formula in a number of ways. Distances, for example, are rarely given to the reader, as they are in the earlier fourth-century Itinerarium Burdigalense and the sixth-century De Situ Terrae Sanctae of Theodosios, which are both known to have circulated within ninthcentury copies. ${ }^{36}$ Where they do appear, most function to situate biblical holy sites with respect to one another. Bethlehem, for example, is described as being six miles from Jerusalem - Bethany, the Itinerary informs us, could be reached by descending for a mile from the Mount of Olives. ${ }^{37}$ Although serving to situate Bernard's route within a tangible geographical space,

34 Itinerary, prologue. On the broader genre of itineraria in the Roman Empire and during Late Antiquity, see Salway, Travel, 22-66; Salway, Sea and river, 43-96; O’Loughlin, Adomnán and the Holy Places, 19-20, with further references.

35 Itinerary, 8. Dutton, Carolingian Civilization, 474. I have substituted Dutton's naming of the field as "Goan« with the name »Tanis«, which better reflects the Latin edition of Ackermann and the Vulgate.

36 Itinerarium Burdigalense, ed. Geyer and Cuntz, 1-26; Theodosius, De Situ Terrae Sanctae, ed. Geyer, 115-125.

37 Itinerary, 16-17. 
these descriptions are not in themselves conclusive of an actual journey and indeed replicate an established consensus about the topography of the Holy Land known to ninth-century audiences from existing sources. The six-mile distance between Jerusalem to Bethlehem, for example, appears in the De Locis Sanctis of Bede, who probably relied on a copy of Ps. Eucherius that was available to him in Jarrow. ${ }^{38}$ The one-mile distance from Jerusalem to the Mount of Olives also appears to have been drawn from the same source, or from the Gospels. ${ }^{39}$ Elsewhere, the Itinerary's knowledge of the Holy Land is more limited - only with respect to Italy does the narrative provide more systematic descriptions of distances between cities. ${ }^{40}$

The Itinerary also frequently breaks with this structure to provide additional historical details about events that coincided with Bernard's journey. Bernard's journey home, for example, leaps abruptly from Jerusalem to Italy, only noting that he and his companions sailed for sixty days. ${ }^{41}$ Bernard's solitary journey from Rome to Mont-Saint-Michel also eschews a description of the stages and distances between these two points. ${ }^{42}$ Instead, the Itinerary addresses the contemporary political instabilities of the 860 s as a backdrop to the journey. The initial stages of Bernard's journey through Italy describe the Muslim capture of Bari and the enslavement of the people of Benevento with whom Bernard and his companions journey to Egypt. ${ }^{43}$ Upon the completion of his journey at Mont-Saint-Michel in Normandy, the narrative then breaks to focus on the broader political instabilities of Bernard's lifetime; from the assassination of Sichard, to the ascension of Louis II and the legal status and relative peace among Christians in the Muslim world. ${ }^{44}$

38 Ps. Eucherius, De Situ Hierusolimitanae Urbis 11, ed. Fraipont, 238-239; Bede, De Locis Sanctis, VII.1, ed. Geyer, 251-280, especially 265, trans. Foley and Holder, 6-25. For an awareness of Adomnán, Bede and Pseudo-Eucherius among Carolingian writers see O’Loughlin, Diffusion, 94-98; O’Loughlin, Symbol gives life, 221-252. Also useful are the earlier studies of Lambot, L'homelie, 26; Bullough, Columba, 111-30.

39 Ps.Eucherius, De Situ Hierusolimitanae Urbis 11, ed. Fraipont, 238-239; Bede, De Locis Sanctis, VI. 1, ed. Geyer, 264265, trans. Foley and Holder, 14, John 11:18. Ps. Eucherius was evidently in circulation in Francia by the eighth century. Cod. Paris, 13348, was produced in northern France in the late eighth century and held in the library of Saint Pierre in Corbie, where it was compiled with a Latin translation of the Pseudo Methodius: Kortekaas, Transmission, especially 67-68. Distances are also described in Bede, De Locis Sanctis VI.1 and VII.1, ed. Fraipont, 262, 264.

40 Itinerary, 3-4.

41 Itinerary, 20.

42 Itinerary, 22.

43 Itinerary, 3-4.

44 Itinerary 22-24. The description of Louis' mediation of the dispute among the Beneventans and their invitation to Louis to rule over them (super eos imperium accepit), would indicate that the text is alluding to the events of the period c. 849-c. 855. Broader discussion of imperium in the Carolingian world, and its historiography, appears in De Jong, The Empire. 
These "ninth-century « vignettes have been valued highly among recent readings of the Itinerary, to the extent that the accompanying passages describing Bernard's experiences in Jerusalem are often subordinated in recent critical commentary as a derivative compilation of earlier sources. ${ }^{45}$ Part of the reason for this negative appraisal is that Bernard explicitly acknowledges his use of Bede in his discussion of the tomb of Christ, which, as the Itinerary states, made a further description of the sepulchre unnecessary (De hoc sepulchre non est necesse plura scriber, cum dicat Beda in historia sua inde sufficientia). ${ }^{46}$ The source in question is Bede's Ecclesiastical History which drew from the earlier De Locis Sanctis penned by Adomnán of Iona around c. $680 .{ }^{47}$ Bernard's description of the Holy Sepulchre, however, does not quote directly from Bede's text and it is not certain if he had direct access to a copy as he wrote the Itinerary. The frequency with which both descriptions intersect implies that he did, or that its descriptions were known to him from other sources. ${ }^{48}$

Within that city [of Jerusalem], with other churches left aside [here], four churches stand out [and] share common walls with each other. One, which lies to the east, contains Mount Calvary and the place where the cross of the Lord was found and it is called the Basilica of Constantine. Another [lies] to the south; a third to the west, in the middle of which is the Sepulchre of the Lord which has nine columns around it, between which stand walls made of the finest stones. Four of the nine columns are before the face of that monument; with their walls they enclose the [tomb] stone placed before the sepulchre, which the angel rolled back and upon which he sat after the resurrection of the Lord was brought about. It is not necessary to say more about this sepulchre, since Bede in his history says enough about it. ${ }^{49}$

Bernard, Itinerary, 11

Bede's emphasis on the precious stone decoration of the Church of the Sepulchre resonates in Bernard's own encounter, as does Bernard's description of four churches in the ecclesiastical complex of the Anastasis and Golgotha. Both scenarios - that Bernard had Bede's text to hand or knew it well - are plausible and support a ninth-century authorial context in which copies of Bede's Ecclesiastical History and De Locis Sanctis, alongside Adomnán's earlier version, are known to have circulated widely..$^{50}$

45 Raymond Beazley's denunciation of the Itinerary in his seminal 1897 study, The Dawn of Modern Geography, is characteristic of sentiments that continue to appear in modern critical engagement of the text. As he states, "His credulity and ignorance are not greater than those of earlier pilgrims; his sufferings appear to have been less than Willibald's; he shows no inventive faculty, like the Antonine or Cosmas, no peculiar breadth of view or culture of style, like Silvia or Arculf «. This is followed by the later description of Jerusalem: "But here is an account (which though brief has been hitherto fairly ample) dwindles into a bare enumeration of sites and churches«, Beazley, The Dawn of Modern Geography, 167-171. See also, Halevi, Bernard, explorer, 27.

46 Itinerary, 11.

47 Bede, Historia ecclesiastica gentis Anglorum 5.16-17, ed. Colgrave and Mynors, 508-512.

48 Copies of the Ecclesiastical History circulated widely in the ninth century. Laistner, Hand-list, 93-102, Becker also lists copies at Reichenau and St Gall: Becker, Catalogi, 20 and 47.

49 Itinerary, 11, Dutton, Carolingian Civilization, 475.

50 On the transmission of Adomnán’s De Locis Sanctis: O’Loughlin, Diffusion, 93-106. 
The internal organisation of the Itinerary also displays some subtle influence from Jerome's Epistola ad Eustochium (no. 108), another text widely copied by the 860s. ${ }^{51}$ Jerome's description of Paula's pilgrimage, for example, traces her journey from Diospolis, to Emmaus and then to Jerusalem, where she visited the Praetorium (her lodging), the tomb of Christ and Mount Sion. ${ }^{52}$ Departing the city, Paula then moved eastwards to Bethany and the tomb of Lazarus, Bethlehem and Shepherd's Fields ${ }^{53}$ After visiting Galilee, Paula's journey travelled through Gaza and then to Egypt, where she journeyed across the five cities of Egypt that evoke the prophecy of Isaiah 19.18. ${ }^{54}$

The description of Bernard's journey through Egypt and Jerusalem follows a corresponding itinerary. Journeying towards Jerusalem, Bernard first visits Ramla (which had replaced Diospolis in the seventh century) and Emmaus, before heading to the hospitium of Charlemagne (imperatoris Karoli) (his lodging place) in Jerusalem. ${ }^{55}$ Like Paula, Bernard's description of the intramural churches of Jerusalem only focuses upon the Holy Sepulchre and Holy Sion, which he describes, and then shifts focus to the sites on the outskirts of the city, at Bethany, Bethlehem and Shepherds' Fields. ${ }^{56}$ Bernard's description of Egypt, like the Epistola ad Eustochium, is also structured around the description of five cities described in the Itinerary as civitates (Fig.1).

51 Jerome's eulogy of Paula is Epistola, 108, ed. Hilberg, 306-351. A copy of the letter was on Iona by the late seventh century, see O'Loughlin, Adomnán and the Holy Places, 248. For wider use of Jerome's letters in the early medieval world, see Matis, Seclusion of Eustochium, 665-689 and Lifshitz, Religious women, 34. For ninth-century copies of Jerome's Letters, see Becker, Catalogi, 9, 17, 25, 32 and 45. On the importance of Jerome and his companions as a model in ninth-century writing, see Contreni, Learning for God, 122-123.

52 Jerome, Epistola, 108, ed. Hilberg, 9, 14.

53 Jerome, Epistola, 108, ed. Hilberg, 10-11.

54 Jerome, Epistola, 108, ed. Hilberg, 14. »In die illa erunt quinque civitates in terra Ægypti loquentes lingua Chanaan, et jurantes per Dominum exercituum: Civitas solis vocabitur una'una.«

55 Itinerary 10-11.

56 Itinerary 11-12. 


\begin{tabular}{|l|l|}
\hline Name & Reference \\
\hline Alexandria & $\begin{array}{l}\text { Ab aquilone est portus illius civitatis; a meridie habet introitum Gyon sive } \\
\text { Nilus, qui rigat Egyptum et currit per mediam civitatem, intrans in mare in } \\
\text { predicto portu. } \\
\text { Itinerary, 6 }\end{array}$ \\
\hline Babylon & $\begin{array}{l}\text { Est itaque in hac civitate patrirarcha domnus Michael, et super totum } \\
\text { Egyptum disoinens gratia Dei ordinem omnium episcoporum et } \\
\text { monachorum et Christianorum. } \\
\text { Itinerary, 7 }\end{array}$ \\
\hline Sitimulh & $\begin{array}{l}\text { His ita se habentibus, redivimus retrorsum per fluvium Gyon III diebus, et } \\
\text { devenimus ad civitatem Sitinulh, } \\
\text { Itinerary, 8 }\end{array}$ \\
\hline Tanis & $\begin{array}{l}\text { Inde navigavimus ad civitatem Tamnis, in qua sunt Christiani multum } \\
\text { religiosi, hospitalitate nimia ferventes } \\
\text { Itinerary, 8 }\end{array}$ \\
\hline Farama & $\begin{array}{l}\text { De Tamnis venimus ad civitatem Farameam, ubi est ecclesia [in honore] } \\
\text { sancte Marie, in loco, ad quem, angelo monente, fugit Ioseph cum puero } \\
\text { et matre, } \\
\text { Itinerary, 9 }\end{array}$ \\
\hline
\end{tabular}

Fig. 1: The five civitates of the Itinerary

\section{Landscapes of Exegesis}

Whether or not this correlation was intentional, Bernard's Itinerary evidently emerged within a literary milieu in which an established tradition of geographical writing about the Holy Land was known to him from other sources. Yet, although Bernard acknowledges his particular use of Bede, the Itinerary is more sophisticated than a straightforward replication of earlier sources and instances of variation between the text and other Holy Land itineraries suggest that Bernard also utilised the Itinerary to address specific exegetical concerns extant among his own community. Bernard's identification of a Church of St John on the Mount of Olives, which commemorated the story of the Pericope Adulterae, offers a clear example of Bernard's exegetical method.

From there we proceeded to the Mount of Olives on whose slope is displayed the place of the Lord's Prayer to [God] the father. Also on the side of the same mountain is the place where the Pharisees brought forth to the Lord the woman caught in adultery; it has a church in honour of Saint John in which is preserved in marble the writing that he wrote on the ground. ${ }^{57}$

Bernard, Itinerary, 14. 
Despite Bernard's claims as a witness, it is doubtful that such a church ever existed as a physical space, because its location within the Itinerary is based upon a straightforward misreading of John 7:53-8.11 which locates the events of the story in the Temple.$^{58}$ This presents two possibilities: either Bernard had misread the pericope, or he worked from a manuscript that omitted the passage, where the woman accused of adultery is brought to Christ at the Temple. ${ }^{59}$ Either suggestion is plausible in view of the complex history of the pericope as a later third-century interpolation often omitted from the earliest Greek copies of the Gospel of John and related Latin translations. ${ }^{60}$

A plausible interpretation for Bernard's "error « is that his conception of the topography of the Mount of Olives had been shaped by his reading of the Gospels in an earlier Latin copy that deviated from the codified Vulgate extant by the ninth century. ${ }^{61}$ Exactly how this misreading entered the tradition familiar to Bernard is unclear, although examples like the Codex Rehdigeranus, where the passage was inserted into older copies of the Latin Gospels by ninth-century scribes, provide us with some sense of how Bernard may have had access to a version of John without such editing, which could have framed his expectation of the landscape of Jerusalem and its hinterland. ${ }^{62}$

Bernard's description of a church dedicated to St John is nevertheless instructive for the way that it reveals Bernard's use of the topos of the physical ecclesia as an exegetical tool to clarify scriptural readings. ${ }^{63}$ The Pericope Adulterae is a particularly compelling example, because it deals with a passage familiar to ninth-century audiences, and emphasised in patristic writing, to be complex and in need of critical commentary. ${ }^{64}$ While there is little indication that the authenticity of the Pericope Adulterae was widely questioned by the 860 s, monastic writers like Bernard would have been familiar with a wealth of older writings in Latin that drew attention to suspicions regarding its validity. ${ }^{65}$ Both Augustine and Jerome, although essentially convinced of the pericope's status as a genuine Gospel story, allude to concerns about its authenticity and its placement within the chronology of Christ's earthly life. ${ }^{66}$

58 "Jesus autem perrexit in montem Oliveti: et diluculo iterum venit in templum, et omnis populus venit ad eum, et sedens docebat eos".

59 John 8.1-3.

60 Knust and Wasserman, To Cast the First Stone, 49-95. ; ibid., 209-248.

61 On the general deviations in the transmission of the pericope, including Ambrose of Milan's own use of divergent versions, see Knust and Wasserman, To Cast the First Stone, 217-231.

62 The eighth or ninth-century Codex Rehdigeranus, in which the passage of John 7:53-8.13 was inserted into the margin of the folio beside an Old Latin translation of the Gospel of John, provides an illustrative example of a practice that was widespread among copying practices in Bernard's lifetime, Knust and Wasserman, To Cast the First Stone, 229-232; Loew, Date of the Codex Rehdigeranus, 569-570; Vogels, Codex Rehdigeranus.

63 O'Loughlin, Adomnán and the Holy Places, 55-57.

64 See note 68 .

65 These have been surveyed in Knust and Wasserman, To Cast the First Stone, 209-248.

66 Augustine's De adulterinis coniugiis (dated 419), which was later invoked at the Synod of Paris in 825, provides what is probably the earliest witness to accusations of the pericope's deliberate removal from the Gospel of John, Augustine, De adulterinis coniugiis, 387, ed. Zycha, trans. Wilcox, 107; Concilium Parisiense 825, MGH Conc. 2, 2 p. 498. For A copies of the De adulterinis, see Becker, Catalogi, 5. Jerome's Contra Pelgaium and Rufinus' translation of Eusebius' Ecclesiastical History, which were well known to Carolingian audiences, also expose an awareness of the complex history of the pericope's transmission: Rufinus of Aquileia, 3.39.17. See also Amidon, Church History. On the transmission and use of Rufinus in the Carolingian world, see McKitterick, History and Memory, 227-235. Copies were present at Fontelles, Reichenau and St. Gall by the ninth century: Becker, Catalogi, 3, 9, 224. 
The Itinerary, however, cuts through such ambiguity by offering eyewitness testament to the existence of a church on the Mount of Olives dedicated to the Evangelist in whose Gospel the story appears. Drawing upon an established exegetical device of the stone vestigia, equally familiar to a monastic audience trained within the tradition of Augustinian exegesis, the Itinerary also proceeds to describe the marble stone (lapide marmoreo), that marks the spot where Christ had drawn in the earth (quam Dominus scripsit in terra) ${ }^{67}$

Bernard's visit to the location of the Pericope Adulterae also resonates with a renewed interest in the story by the mid-ninth century due to its associations with penance and justice. ${ }^{68}$ The story appears in its most explicit form in the Lothar Crystal (probably dated 855-869), which depicts a sequence from the life of Susanna, (an established typology for the Adulterous Woman), flanked by quotations from the Vulgate text of John 7.53-8.1. ${ }^{69}$ An image of the scene also adorns the cover of the Codex Aureus of St Emmeram commissioned in 870 by Charles the Bald, with further illuminations of the pericope also known from ninth-century copies of the Carmen paschale and Sedulius Scottus' biblical commentaries. ${ }^{70}$

In placing the Church of St John on the Mount of Olives, the Itinerary also locates the Pericope Adulterae in a geographical context familiar to ninth-century audiences from the sequences of the Lenten liturgy. As an essentially redemptive story which emphasises the salvific power of Christ, the pericope appears in Latin lectionaries as early as the fifth century in connection with the Paschal cycle. In Rome, the story served as the prescribed reading assigned to the third Saturday of Lent, observed at the church of Santa Susanna, whose biblical namesake was widely recognised in the ninth century as a typological parallel to the Pericope Adulterae. ${ }^{71}$ Carolingian liturgies of the eighth to tenth centuries also demonstrate a continued association of the story with the readings ascribed to the Lenten fast. ${ }^{72}$

The Itinerary's geographical placement of the Church of St John on the Mount of Olives accords with its typological connection to Lent. After leaving Jerusalem and Gethsemane, Bernard first visits the Church of the Last Supper, in which Christ was betrayed, before journeying to the Mount of Olives where Christ prayed to the Father.

67 Augustine, De Doctrina Christiana, ed. J. Martin; O'Loughlin, Exegetical purpose, 38-42, Moore, Architecture of the Christian Holy Land, 39-52. For copies of De Doctrina Christiana, see Becker, Catalogi, 5, 25, 32, 39, 45.

68 See notes 68-70 above.

69 Flint, Susanna and the Lothar Crystal, 61-86; Kornbluth, Engraved gems, 36-46; Tkacz, Susanna, 101-153.

70 München, Staatsbibliothek, München SB Clm 140; Dielbold, Verbal, visual, and cultural literacy, 89-99; Antwerp, Plantin-Moretus Museum, MS M.17.4; Martyr-Harting, Ottonian Book Illumination, 1.72-73; Sedulius Scottus, Collectaneum Miscellaneum, 13.2.14, ed. Simpson, 54; See also Knust and Wasserman, To Cast the First Stone, 321-323.

71 The Harley Golden Gospels (British Museum MS Harl. 2788), produced c. 800-c. 825, lists the observance: Frere, Roman Liturgy, 37 (no. 81). On the significance of the story of Susana as a typology of John 7.53-8.11, see Kornbluth, Susanna Crystal, 25-39; Flint, Susanna and the Lothar Crystal, 61-86.

72 The only additional development being the addition of the chant Nemo Te (from the Vulgate text of John 8:10-11), as the antiphon for the Lenten communion. This is taken from the Vulgate: „Erigens autem se Jesus, dixit ei: Mulier, ubi sunt qui te accusabant? nemo te condemnavit? Quæ dixit: Nemo, Domine. Dixit autem Jesus: Nec ego te condemnabo: vade, et jam amplius noli peccare«; Knust and Wasserman, To Cast the First Stone, 318. 
From there we proceeded to the Mount of Olives on whose slope is displayed the place of the Lord's prayer to [God] the father. Also on the side of the same mountain is the place where the Pharisees brought forth to the Lord the woman caught in adultery; it has a church in honour of Saint John in which is preserved in marble the writing that he wrote on the ground.

Bernard, Itinerary, 14

Each of these churches commemorates episodes familiar to Roman and Carolingian audiences through the readings and scriptural pericopes assigned to the final Lenten weeks before Easter Sunday. A listing within the Roman lectionary indicates that both events formed part of the commemoration on the final Saturday of Lent, accompanied by readings from chapter 13 of the Book of Daniel. ${ }^{73}$ By the ninth century, these were also accompanied by sermons delivered on Holy Thursday that recalled the importance of both events as symbols of Christ's humility and sacrifice. ${ }^{74}$ The Itinerary's placement of these churches within a single travel sequence thus brings to the fore motifs and stories that resonated within ninth-century liturgical custom and reveals Bernard's conception of the Holy Land as one closely aligned to ninth-century interests in the redemptive story of the Passion and liturgical celebrations linked to the Paschal cycle. ${ }^{75}$

\section{Paschal Landscapes}

At the centre of the Itinerary's exegetical map lay the tomb of Christ and the physical centre of the world, which Bernard identifies by the description of four chains that ran to the centre of a paradise.$^{76}$ Following Bede's directive, Bernard proceeds to describe the four constituent churches of the complex of the Church of the Holy Sepulchre.

Within that city [of Jerusalem], with other churches left aside [here], four churches stand out [and] share common walls with each other. One, which lies to the east, contains Mount Calvary and the place where the cross of the Lord was found and it is called the Basilica of Constantine. Another [lies] to the south; a third to the west, in the middle of which is the Sepulchre of the Lord which has nine columns around it, between which stand walls made of the finest stones. ${ }^{77}$

Bernard, Itinerary, 11

Comparing the two accounts it becomes apparent that Bernard's description of the tomb deviates from Bede's model, despite explicitly acknowledging it. Bede, for example, describes the tomb as an aedicule furnished with twelve columns and twelve hanging lamps. ${ }^{78}$ Bernard, however, reorganised this architectural plan to describe a structure surrounded by nine columns - four of which are placed directly before the entrance to the tomb.

Flint, Susanna and the Lothar Crystal, 69-71, with further references. See also Frere, Lectionary, no. 81.

74 Hrabanus Maurus, Homily, 15 (In coena Domini), ed. Migne, 30D-33A; Hrabanus Maurus, Homily, 13 (In feria IV), ed. Migne, 27B-29A, and the Homily by Smaragdus of St-Mihiel, Homily, 2 II, ed. Migne, 163-166; Etaix, L'homéliaire, 211-240; Chazelle, Crucified God, 152-155.

75 Chazelle, Crucified God, 149-150.

76 Itinerary, 11.

77 Itinerary, 11.

78 Bede, Historia ecclesiastica, 5 V.17. 
Four of the nine columns are before the face of that monument; with their walls they enclose the [tomb] stone placed before the sepulchre, which the angel rolled back and upon which he sat after the resurrection of the Lord was brought about. It is not necessary to say more about this sepulchre, since Bede in his history says enough about it. ${ }^{79}$

Bernard, Itinerary, 11.

This re-arrangement is unlikely to reflect a physical change to the structure of the tomb but a typological one that attached specific importance to the numerological values of nine and four. In this respect, the Itinerary reveals its use of an established exegetical device that had also been employed by both Gregory and Bede, for whom numerological readings of architectural plans had informed their earlier descriptions of the Sepulchre, the Tabernacle and Solomon's Temple. ${ }^{80}$ Drawing upon this tradition, Adomnán's earlier description of the tomb of Christ had also been shaped by a numerological code that placed Christ's burial at the centre of twelve pillars (the disciples), decorated by twelve lamps and flanked by three walls, three altars and three partitions. ${ }^{81}$

Bernard's use of the numbers nine and four offer different, although probably equally meaningful, numerical values that also emphasise the position of the Sepulchre at the intersection between the heavenly and earthly paradise. What we cannot know from the Itinerary is exactly how they were intended to be read by Bernard's audience, because the text itself offers no definitive reading. Nevertheless, the emphasis on recurrent numerical values in the description of the Sepulchre and elsewhere in the narrative, to which we will return, alludes to Bernard's own familiarity with existing numerological conventions and his ability to adapt them to stress alternate allegorical readings.

Bernard's sepulchre is organised around the numerical values of nine and four. By the mid-ninth century the number nine was most commonly associated with the number of angelic orders that surrounded the heavenly throne, a reading that drew upon the De Coelest $i$ Hierarchia of Pseudo Dionysius the Areopagite which was known by the 860 s from the Latin translations of John Scotus Eriugena, an earlier version by Hilduin and the extensive commentaries of Anastasius Bibliotecarius. ${ }^{82}$ The number four also held particular significance for ninth-century audiences owing to its association with the Gospels and as the number of cardinal directions - two readings that had been exegetically linked in earlier centuries. ${ }^{83}$ Bernard's arrangement of four pillars (the number of Gospels) before the tomb of Christ - a symbolic arrangement that denotes their primacy over the other five (evoking the Pentateuch) - was likely intended to evoke one, or several, of these existing typologies. ${ }^{84}$

79 Dutton, Carolingian Civilization, 475.

80 Augustine, De Doctrina Christiana, 3 III.1-37, ed. Martin. See the comments in Connolly, On the Temple, xxv-xxviii, see Laistner, Hand-list, 75-77. Bede, De tabernaculo, I. 25-30, ed. Hurst 25-30, trans. Holder, 28-29. Bede, De templo, 18.7, 18.10-13, 20.12, 22.3-4, ed. Hurst, 141-234. For copies of this text, see Laistner, Hand-list, 70-74.

81 Adomnán, De Locis Sanctis, 1.1.3, ed. Bieler, 87, trans. Wilkinson (second edition), 171.

82 Pseudo-Dionysius the Areopagite, De Coelesti Hierarchia, ed. Heil, 26, trans. Parker. Rorem, Eriugena's Commentary. On the history of the reception of Pseudo-Dionysius the Areopagite: Rorem, Early Latin, 601-614; Delaporte, He darkens, 219-246. For writers such as Dhuoda, the nine standing (steterunt) angelic orders prefigured the return of the tenth angelic order at the end of days Dhuoda, Liber Manualis, 9.3-4, ed. and trans. Thiebaux, 212-215. Anastasius Bibliothecarius also had access to a copy of the De Coelesti Hierarchia, Forrai, Notes, 74-10o.

83 Dhuoda also links four to the number of Gospels and the preaching of the Gospels in four directions throughout the world, Dhuoda, Liber Manualis, 9.3, ed. and trans. Thiebaux, 212-213.

84 Itinerary, 11. 
If this particular reading is correct, Bernard's description of the Sepulchre is reordered and rendered Christo-centric: Christ's earthly tomb is surrounded by columns that number the books that prophesy and detail his life, death and resurrection.

This is a central theme that emerges in other sections of the Itinerary as the geographical focus of Bernard's journey moves beyond the Sepulchre itself and explores the wider landscape of churches and holy sites testifying to Christ's redemption of human sin. Although the Itinerary's internal topography cannot be correlated directly with the liturgical arrangements of a single ecclesiastical or monastic community, Bernard's conception of Jerusalem as a physical space is evidently organised in topographic parcels that resonate with liturgical themes observed in Rome and Francia by the 860 s. ${ }^{85}$ From the Sepulchre, Bernard proceeds directly to Mount Sion and bears witness to the scenes of Christ's washing of the feet and the trials of his final hours, which the Itinerary locates in the church dedicated to Saint Symeon. ${ }^{86}$

Moreover, there is in that city another church to the south on Mount Sion which is called [the church] of Saint Symeon. In that church hangs the crown of thorns.

Bernard, Itinerary, 12

The association of Mount Sion with the tribulations of Christ was already well established at the time of the Itinerary's composition. The Itinerary, however, is the only example among the Holy Land itineraries pre-dating 1000 to locate a church dedicated to Saint Symeon over these relics. Although often perceived as an error derived from Bernard's misunderstanding of the church, the dedication of the ecclesia to Symeon can be seen to draw together several themes that emphasised the messianic status of Christ also familiar to ninth-century audiences from the themes of liturgy and earlier patristic writing.

The Sancti Symeonis, to whom the church is dedicated in the Itinerary, is to be identified as the figure described in Luke 2.22-40, to whom Mary and Joseph presented the infant Christ at the Temple. ${ }^{87}$ Although celebrated separately at the feast dedicated to the Purification of the Virgin, which was also paired with the commemoration of the Lord's circumcision, the reading of Luke 2.22-40 that accompanied the observance was already understood by the ninth century as a prefiguration of Mary and Christ's suffering during the Passion. The commentaries on the Gospel of Luke by Ambrose and Bede, as well as Bede's Homily to accompany Easter Sunday, all emphasise the symbolic role of Christ's circumcision and presentation at the Temple as a model for his future suffering. ${ }^{88}$

85 Chazelle, Crucified God, 14-73.

86 Itinerary, 12.

87 Luke 2.22-40.

88 Ambrose, Expositio 22-24, ed. Schenkl, 71-73; Bede, Homelia, 1.18, ed. Hurst, 128, trans. Martin, 182. See also Del Giacco, Exegesis and Sermon, 9-29. 
Symeon's words recounted in Luke 2:29-32, the Nunc Dimitis, were also familiar to monastic audiences in the ninth century as the canticle sung at Compline and as one of a number of canticles that accompanied the antiphon Alleluia during the mass celebrations of Paschal week. ${ }^{89}$ Whether or not Bernard intentionally sought to evoke the writings of Ambrose or Bede, his exegetical geography emerges from a similar tradition of thinking: Bernard's church of Saint Symeon, dedicated to the holy figure who prophesies Christ's Messianic status and future suffering, is furnished with the relic of the Crown of Thorns that confirms the fulfilment of this prophecy. ${ }^{90}$

Moving outside of the walls, the focus of the Itinerary extends to other sites linked with Christ's betrayal, Ascension, then to Bethany and the site of Lazarus' tomb.${ }^{91}$ This particular topographical sequence follows an established geographical conception of the Holy Land that corresponds to the key motifs and stories common in the western Paschal liturgy by the 860s. ${ }^{92}$ Isidore of Seville's discussion of the Holy Week in the De Ecclesiasticis Officiis, for example, follows a similar exegetical itinerary that simultaneously stresses the salvific role of Christ and his humility..$^{93}$ Isidore's description of the observations of Holy Thursday, centred on the washing of the disciples' feet and the prefiguration of the Eucharist in the Last Supper all find corresponding motifs in Bernard's narrative through the identification of churches at the locations of these events. ${ }^{94}$ Lazarus' tomb in Bethany also brings into focus another site and story widely utilised by ninth-century exegetes for its association with penance and spiritual rebirth through Christ. ${ }^{95}$ For ninth-century audiences, these episodes conveyed further exegetical relevance as symbols of hope and as examples of redemption through penance. ${ }^{96}$ Combined, each of these biblical topoi, reveal Bernard's conception of the Holy Land to be one defined principally by the redemptive story of Christ and the efficacy of penance.

89 Frere, Kalendar, 1, 5, 92-94. It appears in the Harley Golden Gospels: Frere, Roman Liturgy, nos. 8 and 42, Hiley, Western Plainchant, 30.

90 A similar link is also made in Hrabanus Maurus, Expositio in Matthaeum, ed. Löfstedt, 741.

91 Itinerary, 12-16.

92 The homilies of Bede also focus on these stages: Bede Homelia, II.4, ed. Hurst, 207-213, trans. Martin and Hurst, 33-41; Bede Homelia II.4, ed. Hurst, 207-213, tr. Martin and Hurst, 33-41; Chazelle, Crucified God, 14-73.

93 Isidore of Seville, De Ecclesiasticis Officiis, I.27 [28]-I.29 [280], ed. Lawson, 31-34, trans. tr. Knoebel, 50-51. This text circulated widely by the ninth century and had been commonly used by Anglo-Saxon missionaries in the eighth century. On the prevalence of the text in Anglo-Saxon England, see Lapidge, Anglo-Saxon Library, 39-43 and Levinson, England and the Continent, 280-290.

94 Itinerary, 12-14.

95 Alcuin, Commemoratorium in Joannem, ed. Migne, 743-1008, especially 896-903; Hrabanus, Expositio in Mattheum, 6., 45-51, 552, Radbertus, Expositio in Matheo IX-XII, 2854-61 and 3499-514, ed. Paulus, 1018 and 1038-39. Earlier influence derived from Augustine, In Iohannis evangelium tractatus cxxiv, 44, ed. Willems, 3-5 Gillis, Heresy and dissent, 97-98. This is a theme originally addressed in Gregory the Great's Homily 26, which was recited on the Octave Sunday of Easter, Gregory the Great, Homily, 26, ed. Migne, 1200B-1201B, trans. Hurst, 205-206.

96 In Carolingian liturgy, these observances coincided with the reconciliation of penitents and the blessing of the chrism in the church on Holy Thursday: Chazelle, Crucified God, 35. 


\section{Landscapes of Redemption}

These themes only become more apparent, however, when the topography of Jerusalem and the Holy Land is situated within the wider geography that the Itinerary presents internally. Bernard's initial journey to Jerusalem proceeds from Egypt, but does not extend further north than Jerusalem itself. Traditional interpretations of the Itinerary have tended to assume that the omission of holy sites north of Jerusalem derived from local political instabilities that prevented Bernard and his companions from travelling further north. Yet, this rather literal interpretation overlooks the relationship between Bernard's experiences in Jerusalem and Egypt as a literary pairing that reinforces the text's central focus on the redemptive message of the Easter story. Indeed, Bernard's initial journey through Egypt towards the Holy Land functions as a counterpart to the Gospel topography by bearing witness to sites representing established Old Testament typologies linked with the Paschal theme.

The typological connection between Christ's final hours in Holy Week and the Israelite exodus had already been firmly established in western liturgical and exegetical consciousness by the seventh century and continued to be reinforced by the circulation of these earlier works in Bernard's lifetime. ${ }^{97}$ Isidore of Seville in the De Ecclesiasticis Officiis and Bede's Homily on Easter, both known to ninth-century audiences, both explicitly connect the two. ${ }^{98}$ Within Bernard's Itinerary these typologies are rendered as a physical geographical dichotomy in which Bernard moves between sites that evoke the transition between the Old and New Laws and traces the footsteps of the Israelite captivity and liberation from Egypt. Crossing the five civitates of Egypt, which evoke the Israelite cities of Isaiah 19:18 (also noted by Jerome), Bernard is brought into contact with the former city of Pharaoh and the granaries (horrea) of Joseph. ${ }^{99}$ In Tinnis (Thaneos), Bernard describes the bodies of those "slaughtered in the days of Moses ", which confirms to his readers the authenticity of the miracles performed by Moses before Pharaoh recalled in Psalm 77 [78] and explicitly links the Itinerary to its Paschal theme.

This city, however, has no land without churches and the plain of Thaneos is found there. In it in the likeness of three walls lie the bodies of those who were slaughtered in the time of Moses. ${ }^{100}$

The salvific tenor of Psalm 77 [78], which extolls God's deliverance of his chosen people, had secured its position within western liturgies long before the ninth century, although by the 860 s it was most often encountered as part of the Paschal cycle where readings of the Psalm appear among a number of ninth-century liturgical manuscripts for the Easter ordines. ${ }^{101}$

97 Chazelle, Crucified God, 29, 134, with further references.

98 Isidore of Seville, De Ecclesiasticis Officiis, 32 [31], ed. Lawson, 35-38, trans. Knoebel, 54; Bede, Homilia, 2 II.7 ed. Hurst, 225-232, trans. Martin and Hurst, 61-65. See also Chazelle, Crucified God, 29, 162.

99 The Israelite captivity and liberation were also frequently recounted in the Lenten and Easter liturgy. It appears in the ninth-century lectionary of Corbie (also called the Comes of Leningrad: Frere, The Lectionary, LVI-LXXXV, [8-11]

100 Itinerary, 8.

101 Andrieu, Les Ordines, nos. 84, 368; Chazelle, Exegesis in the ninth century, 167-187. The connection between Psalm 77 [78] and the raising of Lazarus also appears in Jerome's Homily 11, which was delivered in Lent, Jerome, Homiliae, 11 and 86, ed. Morin, et al., trans. Deferrari, 79-89 and Ewald, 208. 
A continuation of the Old Testament typological theme of salvation and its Paschal counterpart is recalled in a later episode of the Itinerary when Bernard visits Habakkuk's field on the route to Bethlehem, from which Habakkuk was believed to have sent food to Daniel, imprisoned in the lions' den. ${ }^{102}$

Besides [those sites], when we went out of Jerusalem, we crossed over to Bethlehem where the Lord was born, which was six miles [away]. A field was shown to us in which Habbakuk was working when the angel of the Lord ordered him to carry the lunch to Daniel in Babylon ... ${ }^{103}$

Bernard, Itinerary, 17

The Itinerary is the only example of a pilgrimage itinerarium to describe Habakkuk's field (drawn from Daniel 14:33-36), and reveals Bernard's particular interest in salvific themes and typologies drawn from the Book of Daniel. As we have seen, Bernard's six-day imprisonment in Babylon deliberately echoes the experiences of the prophet Daniel, but also brings to the fore a symbolic motif that links the themes of incarceration and liberation with Christ's death and resurrection. Since as early as the fourth century, Daniel's incarceration in Babylon had been widely understood by Christian exegetes as a model for Christ's resurrection, but by the mid-ninth century, had been augmented by a further understanding of Daniel and Habbukuk's story as confirmation of God's reward for enduring faith and eventual Christian triumph over evil. ${ }^{104}$ Hrabanus Maurus' commentary on Daniel is characteristic of the multi-layered interpretation of the story that existed by Bernard's lifetime and drew from the earlier traditions of Jerome and Augustine who also stressed the duality of its interpretation. ${ }^{105}$ Although Bernard shows no awareness of Hrabanus' writings, the Itinerary's topographical focus on sites connected with typological themes of salvation and divine intercession recalled in the Book of Daniel, recreates a topography that resonates with broader exegetical concerns of writers like Hrabanus active in the same decades.

102 Daniel 14:33-36

103 Itinerary, 17.

104 The subject of Daniel as a prefiguration of Christ and the resurrection appears in the writings of Hippolytus of Rome, In Danielem, 31.2, 39.7, ed. Lefèvre, which develops the parallel with Christ's Resurrection, Hilarius of Poitiers, De Trinitate, 10.45-46, ed. Smulders, 499, Jerome, Commentarii in Danielem, ed. Migne, 491-584., Maximus of Turin, Sermon 21, ed. Migne, col. 576, Richardson. Prudentius' Hymns, 104-107. See also, Saxon. The Eucharist, 107-111. Hrabanus Maurus, Allegoriae in sacram Scripturam, ed. Migne, cols. 884ss., Haimo of Auxerre, Homiliae de tempore, 28, ed. Migne, col. 194.

105 De Jong, Old law and new-found power, 161-176; De Jong, Empireas ecclesia, 191-226; Shimahara, Daniel et les visions, 19-32; Palmer, Apocalypse, 165-167, Zier; Interpretation of Daniel, 43-78, especially 58-59; Webb, Knowledge will be manifold, 307-357. 
Like Psalm 77 [78], to which it was typologically linked in the Gospel of John, recognition of the story of Habakkuk's field as a prelude to the Eucharist and Christ's resurrection encouraged its use within western liturgical cycles during Lent and Easter. ${ }^{106}$ The sixth-century Libri Comptis, for example, lists a reading of the pages on the Tuesday of Passiontide which was still being observed at the Abbey of Cluny in the early tenth century, according to the surviving lectionaries. ${ }^{107}$ By locating the field in Bethlehem, a detail which is omitted from the descriptions of Daniel 14:33-36, the Itinerary also links Habakkuk's field with Bernard's subsequent journey to the birthplace of Christ. ${ }^{108}$ Like the earlier example of the church of Saint Symeon, Bernard's association of Habbukuk's field with Bethlehem presents a further example of a typological location that links together themes relating the Messianic status of Christ proclaimed in his infancy with those anticipating his death and resurrection in adulthood. By the 860s, Habakkuk's prophecy (Habakkuk 3:2), was varyingly interpreted both as a typological prelude to Christ's Nativity in Bethlehem and his Crucifixion. As one of the Lenten canticles recited during the Easter vigil, the third book of Habakkuk was also understood as further confirmation of God's deliverance of his people and their triumph over adversity. ${ }^{109}$ Bernard's linking of Habbukuk's field with Bethlehem thus brings together these typologies within a single geographical sequence that works to emphasise Christ's redemptive message and resonate with the parallels established within the Paschal liturgy. ${ }^{110}$ Like Jerusalem, the landscapes of Egypt and the wider Holy Land that Bernard encounters are, from the outset, encoded with salvation and the promise of redemption.

106 John 6.25. A typological connection between Habbukuk 3 (the Canticle of Habbukuk), is also drawn by Bede's commentary of Habbukuk, see Bede, In Canticum Abacuc, ed. Hudson, 381-382, trans. Connolly, 65-66. The interpretation of Psalm 77 as a prefiguration of the Eucharist is established in Cassiodorus' Commentary on the Psalms, Cassiodorus, Expositio Psalmorum, ed. Adriaen, 708-732, trans. Walsh, 250-275. Cassiodorus' work is widely attested in the ninth-century manuscript tradition, see Halporn, Manuscripts of Cassiodorus, 388-396. General discussion in Copeland and Sluiter, Cassiodorus, Expositio Psalmorum, CA. 540, 210-231. Cassiodorus' commentary is also listed in the archival lists published by Becker at St Riquier, Fontelles, Wurzburg and St Gallen; Becker, Catalogi, 10, 26, 34, 40, 47 and 55.

107 Liber comitis, ed. Migne, col. 502. The passage appears in a tenth-century lectionary from St Gall (Zurich, Zentralbibliothek, MS C 77, fols. 106r-107r), see Euw, St. Galler, 1:433-435. For the formation of the Liber comitis, see Noble, Literacy and the papal government, 8-133, especially 100 and Vescovi, Eschatological mirror, 53-80.

108 Itinerary, 17. Bernard's description of the Cave of Bethlehem and his emphasis on the Lord's crying appears to be influenced by the earlier descriptions of Jerome, Epistola 108, 10.7, on which, see Cain. Jerome's Epitaph on Paula, 256-258. Bernard's description of altars within the cave, and the emphasis on the cries of the infant Christ also overlap with the descriptions provided in Jerome's Homily on the Nativity, which was well known to Carolingian audiences, Jerome, Homily, 88, ed. Morin et al., trans. Ewald, 221-228.

109 The correlation derives from a misreading of Habbukuk 3, which encouraged a reading of the text as a typology of Isaiah 1.3. The connection was certainly known through the ninth century: Pseudo Matthew, Libri de nativitate Mariae, ed. J. Gijsel. On the transmission of this text in the Carolingian world, see Leyser, From maternal, 30-35.

110 Bede, In Canticum Abacuc, ed. Hudson, 383, trans. Connolly, 68. Bede, In Canticum Abacuc, ed. Hudson, 381-409, trans. Connolly, 65-95. For wider use of the Canticle of Habukkuk in western liturgy, including Iberia, see Hornby and Maloy, Music and Meaning, 244-302. 


\section{Penitence and the Journey of Redemption}

This correlation is made explicit in the opening and closing chapters of the Itinerary, which begins and ends by disclosing the political and social disarray across southern Italy from the assassination of Sichard in 839 until the year of Bernard's journey in c. 867. ${ }^{111}$ At the very beginning of the narrative, as Bernard crosses into Muslim territory, the Itinerary describes the thousands of Christian captives transported to Africa:

Departing from Bari, we walked south for ninety miles until [we came] to the port of the city of Taranto, where we found six ships in which there were nine thousand Christian Beneventans held captive. In two ships which left first for Africa there were three thousands captives; in the next two departing ships similarly carried three thousand to Tripoli. ${ }^{112}$

Bernard, Itinerary, 4

It is not until the final chapters, however, that the Itinerary situates such events within a broader moralistic framework that emphasises the unjust killing of Sichard, for which the "Christians of Benevento gravely broke Christian law « (legem christianorum) ${ }^{113}$ The enslavement of the people of Benevento is thus presented in the Itinerary as an ordained consequence of their transgression and draws an immediate parallel with the Israelites of the Old Testament. Within this moralistic framework, the Caliphate, which the Itinerary describes as "Babylon«, looms large as the instrument through which divine chastisement is implemented within Bernard's ninth-century world. Bernard's description of contemporary events in southern Italy in the reign of Louis II is consequently drawn into a Biblical model of transgression and redemption: the Beneventans are enslaved by the Babylonians for their transgression of Christian law.

Yet, like the Old Testament prototype, the Itinerary is also replete with symbols that stress the temporality of the Beneventan chastisement at the hands of the earthly Babylon. Such a reading is achieved in the Itinerary by drawing upon established Biblical parallels that, as we have seen, evoked the Paschal image of the Israelite exodus from Egypt. ${ }^{114}$ Interwoven throughout the Itinerary are further reminders of the previous empires and past kings that had fallen in accordance with divine will. The legacy of Babylon, in particular, casts a shadow over the narrative, both as a reference to the biblical Babylon and Bernard's identification of the Caliphate as the Babylon of his own time. ${ }^{115}$ Although historically accurate, the anachronistic use of the term "Babylon of Egypt « to describe Fustat appears to be a deliberate conflation of the biblical and Abbasid ages, for elsewhere in the Itinerary Bernard shows a clear awareness of the contemporary ninth-century names for the cities he visits. ${ }^{116}$

111 Itinerary, 24.

112 Itinerary, 4.

113 "Beneventani principem suum Sichardum per superbiam interfecerunt, et legem Christianroum multum destruxerunt", Itinerary, 24.

114 See notes 96-97.

115 Itinerary, 7: "In quod intrantes navigamus ad meridiem diebus VI, et venimus ad Babyloniam Aegypti, ubi reganvit quondam pharao, rex, sub quo aedificavit Joseph VII horrea adhunc manentia."

116 Ramla, rather than Diospolis, for example, is given as the approximate location of the tomb of Saint George as Bernard approaches the Holy City, Itinerary, 10. The ambiguous names of El Baracha and El Ariza, which appear as Latinised versions of Arabic toponyms, provide another case of Bernard's awareness of contemporary realities of the ninth-century landscape, Itinerary, 9. 
The Itinerary's ambiguous conflation of the biblical and Egyptian Babylon, however, facilitates a broader understanding of Bernard's journey as an exegetical exploration of the temporal nature of human rule. Travelling to Egypt, Bernard ventures to Fustat, which the narrative identifies as Babylonia of Egypt (venimns ad Babyloniam Aegypti), and notes that King Pharaoh once reigned there (regnavit quondam pharaoh rex). ${ }^{117}$ Observing the seven granaries (horrea) built by Joseph, an established typological identification for the pyramids by the ninth century, the Itinerary alludes to the dreams of Joseph recalled in Genesis 41 and the prophecy of seven years of prosperity. ${ }^{118}$

Passing through Tinnis, Bernard and his companions then bear witness to the field in which Moses performed miracles before Pharaoh - an encounter that connects Bernard's topography to the teachings of Psalm 77 [78], which recalls God's intercession and kindness to the people of Israel. ${ }^{119}$ Similarly, upon entering Bethlehem, Bernard was shown (ostensus) the field from which the angel of the Lord commanded Habakkuk to bring the meal to the imprisoned Daniel in Babylon. ${ }^{120}$ This is accompanied by a further note that Babylon is located to the south (quae est ad meridiem). ${ }^{121}$

The story of Habbukuk is drawn from the fourteenth chapter of the Book of Daniel in the Vulgate, but the Itinerary supplements its details by locating the former royal capital of Nebuchadnezzar within a geographical place to the south. ${ }^{122}$ This intentional geographical shift immediately calls to mind the apocalyptic prophecy of »the King of the South " of Daniel 11, a well-known eschatological motif by the ninth century. ${ }^{123}$ In the next line, Bernard reinforces this prophetic association. ${ }^{124}$ Babylon used to be the city from which Nebuchadnezzar reigned but is now inhabited only by beasts and serpents ("quam nunc serpentes ac bestiae inhabitant «). ${ }^{125}$ The image of the abandoned royal city, inhabited by beasts, is a description that evokes the prophecy of Isaiah 13.21-22 which anticipates the destruction of Babylon. ${ }^{126}$ Combined, Bernard's journey across Egypt and his visit to the field of Habakkuk form a literary pairing that recalls past kingdoms and rulers whose temporal power was brought to a close as a result of divine intervention. Implicit within this reading is an exegetical model that invites its readers to draw similar conclusions about events in their own time.

117 Itinerary, 7.

118 Genesis 41.5-7, Gregory of Tours, Historia Francorum, 1.10, ed. Migne, 167B, trans. Thorpe, 74.

119 Psalm 77 [78]: 12, „Coram patribus eorum fecit mirabilia in terra Aegypti, in campo Taneos". For the liturgical significance of this psalm, see note 133 .

120 Itinerary, 16.

121 Itinerary, 16. "A loco nativitatis Domini, qui fuit VI. Millario, ostensus est campus, in quo laborate Habbukuk, quando angelus Domini jussit eum prandium ferre Daniueli in babyloem, quae est ad merideim, ubi regnavit Nabuchodonosor: quam nunc serpents ac bestaie inhabitant."

122 Daniel 14.33-40, which locates Daniel's prison in Babylon.

123 Genesis 41.5-7. Gregory of Tours, Historia Francorum 1.10, ed. Migne, 167B, trans. Thorpe, 74.

124 Itinerary, 16; Daniel 11.11.

125 Itinerary, 16.

126 Isaiah 13.21-22, "Sed requiescent ibi bestix, et replebuntur domus eorum draconibus, et habitabunt ibi struthiones, et pilosi saltabunt ibi; et respondebunt ibi ululæ in ædibus ejus, et sirenes in delubris voluptatis." 


\section{Numerological Values}

Further confirmation of this biblical parallel is offered throughout the Itinerary by the recurrence of numerological signs in the landscape that carried established allegorical meanings linked to the finite nature of the human world. ${ }^{127}$ Although we can only conjecture how these numerical values were read by the specific audience intended for the Itinerary, the use of numerological calculation as a method of exegesis was nevertheless a familiar one by the mid-ninth century, and can be seen most explicitly in Dhuoda's own calculations in Book Nine of the Liber Manualis (penned c. 841-843) and the writings of Hrabanus Marurus which drew heavily from the earlier De tempore ratione, penned by Bede. ${ }^{128}$

The extent of Bernard's awareness of these works in the 860s is difficult to assess from the relatively limited details that the Itinerary itself provides, although the recurrence of particular numbers in the text that possessed common allegorical significance by the ninth century places him broadly within this wider exegetical tradition and indicates his general familiarity with the conventions of ninth-century numerological calculation. The numbers six and thirteen, for example, make regular appearances when associated with Bernard's experiences of the Muslim world. Six appears on multiple occasions and to ninth-century audiences represented a familiar numerological allegory that conveyed the imperfection of humanity and the temporality of the human age. ${ }^{129}$ In scripture, six represents the number of days in which the world was created before the Sabbath (the seventh day); and for earlier commentators such as Augustine and Gregory also functioned as a typological allusion to the "Six Ages of Man« that preceded the Day of Judgement and the heavenly seventh age. ${ }^{130}$

Corresponding interpretations of six as both a human and imperfect number were also a common feature of Carolingian numerological thought by Bernard's lifetime and can be encountered in both the Liber Manualis of Dhuoda (composed c. 841-c. 843) and in the numerous biblical glossia compiled by Hrabanus Maurus. ${ }^{131}$ Thirteen, though less commonly described by patristic authors, is also encountered within scripture as a number associated with rebellion and $\sin .{ }^{132}$

127 Wallis, Number, 181-199; Surles, Medieval Numerology.

128 Dhuoda, Liber Manualis, 9, ed. and trans. Thiebaux, 300-312; Garipzanov, Graphic Signs; Bede, De temporum ratione, ed. Jones, 66, trans. Wallis, 157-158; Darby, Bede and the End of Time, 22-26; Palmer, Ends and futures, 139160; Isidore, De Ecclesiasticis Officiis, 1.42-25, ed. Lawson, 27-29 and trans. Knoebel, 47-49.

129 Bede, De temporum ratione, 66 and translation in Wallis, Bede: The Reckoning, 157-159.

130 Augustine, De Civitate Dei, 11.30, ed. Dombart and Kalb; Augustine, De trinitate libri, 4.4, ed. Mountain,169-172; Augustine, De Genesi, 4.6.13-4.7.14, ed. Zycha; Gregory, Moralia in Job, 35.16.-42.14, ed. Adriaen, 1802, trans. Bliss, 4.691. More negative associations that stressed the imperfection of humanity could also be found within scripture in relation to the value of six. Christ, for example, was subject to six trials on Good Friday and accused six times of demonic possession, On the six trials of Christ: Matt. 26.57-68, 27.1-2; Luke 22:63-71; Luke 26:6-12; John 18: 12-14; John 18.28-38 and John 18:30-19:8. The accusations of demonic possession appear in Matt. 12.24, Mark 3.22, Luke 11:18-19, John 7:20 and John 8:48-52.

131 Dhuoda, Liber Manualis, 9.1-3, ed. and trans. Thiebaux, 210-213. On Hrabanus' numerology, see Schutz, Carolingians, 192-185, with further references, and Ferrari, Il »liber Sanctae Crucis".

132 The appearances of the beast of Revelation number thirteen in scripture and are described in Revelation 13. 
From the perspective of the Itinerary, the numbers six and thirteen are embedded across the structures of the ninth-century Abbasid society that Bernard encounters along his journey. It is signalled at the very outset of the journey: as Bernard and his companions disembark from their boat in Alexandria they are fined thirteen denarii when their letters of recommendation are not recognised by the Muslim governor. ${ }^{133}$ An additional thirteen denarii are also required to secure Bernard's release from prison. ${ }^{134}$ Before disembarking from the ship at Alexandria, Bernard and his companions are forced to pay a fee of six aurei, at which point the text informs the reader that six of Bernard's Frankish denarii and solidi are only worth three solidi and denarii within the Caliphate. ${ }^{135}$ Once in Babylon, Bernard was imprisoned for six days - echoing the experiences of the prophet Daniel imprisoned by Nebuchadnezzar. ${ }^{136}$ Even Bernard's discussion of the Muslim poll tax is woven with numerological symbols which allude to its essential humanity and imperfection. The levying of taxes on wealthier Christians in the Caliphate, as described in the Itinerary, amounts to three, two or one aureus (a combined total of six), or thirteen denarii for poorer Christians. ${ }^{137}$ Bernard's experience throughout the Itinerary consequently confirms to its readers the finite and essentially human nature of the Abbasid »Babylon« and situates its rise and worldly influence within a Christian numerological code.

Like the Itinerary's description of former Biblical rulers, Bernard also employs numerological signs within the Itinerary to draw explicit comparison between Babylon and the Christian world. The Itinerary's emphasis on the numerological temporality of the human Babylon, represented by the number six, is juxtaposed throughout the Itinerary by the recurrence of the number seven in places Bernard and his companions associate with Christian revelation.

133 "Quo urgente, dedit ei unusquisque nostrum pro se XIII denarios, et fecit nobis litteras ad principem Babyloniae", Itinerary, 6.

134 "Qua de causa ostendimus ei litteras de parte praedicti suldani et de parte principis Alexandriae, quod nihil nobis profecit, sed ab illo missi sumus in carcerem, donec post dies sex inito consilio, cum Dei auxilio, tredecim denarius unusquique dedit pro se, sicut et superius", Itinerary 6.

135 Itinerary, 6.

136 Daniel 14.33-40.

137 Itinerary, 7. 
To audiences in the ninth century, seven represented an established numerical value that conveyed an explicit connection to the "End of Days«, and thus was a symbol of divine completeness and unity. ${ }^{138}$ The interpretation is derived from Biblical numerological allegory, where seven is frequently linked to the concept of perfection. ${ }^{139}$ Carolingian numerological writings, inspired by Biblical sequences, elicit a corresponding understanding of these eschatological significations of the number seven..$^{140}$

Bernard's experiences of spaces associated with the Gospel and Old Testament revelation are accordingly described within the Itinerary in a manner that stresses the allegorical significance of the number seven. Apart from Bernard's contact with the seven horrea of Joseph, Bernard also describes seven caves that adorn the shrine dedicated to the Archangel Michael in his recollections of Mons Aureus (San Michele Sul Tusciano in Olevano). ${ }^{141}$ Bernard's broader description of the Holy Land also traces a landscape inscribed with references to the divine value of seven. Within the walled city of Jerusalem, Bernard encounters seven churches (Fig. 2) and then proceeds to visit seven more in the surrounding valleys and hills. Seven sites of revelation are also described across the wider landscape beyond the Holy City.

138 Dhuoda, Liber Manualis, 6.4, 9.1-3 ed. and trans. Thiebaux, 184-185, 212-215; Isidore of Seville, De Ecclesiasticis Officiis, 1.25, ed. Lawson, trans tr. Knoebel, 48-49; Bede, De temporum ratione, 66, trans. Wallis.

139 Within the Book of Revelation, seven forms the eschatological counterpart to the number six as a symbol of divine completeness. Seven spirits, for example, are said to stand before the throne of God and seven seals are also prophesied to be broken at the end of time Revelation 1: 4-7. John's eschatological vision also anticipates seven angels and plagues that will presage the coming of the beast with seven heads (marked 666) before the Day of Judgment, Revelation 8:1-2; Revelation 16; Revelation 13:1.

140 The value of seven as a structuring principal of exegetical interpretation is a recurrent motif of the apocalyptic commentaries of Ambrose Autpertus, Alcuin and Haimo of Auxerre, all of whom drew from the earlier models of Bede and Aldhelm of Malmesbury, Ambrosius Autpertus, Expositio in Apocalypsi VI, ed. Weber, 465-551; Haimo, Expositio in Apocalypsin, ed. Migne, 1019-1020 and Darby, Bede and the End of Time, 60-61. Bede's emphasis on the seven-fold structure of sacred time in the De tempore ratione is probably the better known of these examples: Bede, De temporum ratione, ed. Jones, 66, trans., 159. Dhuoda's Liber Manualis, composed between c. 841 and c. 843, and likely in Bernard's lifetime, also reflects the general permeation of this knowledge beyond strictly monastic circles. Dhuoda stresses the numerological value of "seven" as the symbol of the seven gifts attributed to the Messiah in Isaiah 11.12, Dhuoda, Liber Manualis, 6.4, 9.1-3, ed. and trans. Thiebaux, 184-187, 212-215. The convention of situating descriptions of landscape within a numerological model is not unique to Bernard's Itinerary, as recent discussions of the ninth-century Hiberno-Latin text of the Nauigatio Sancti Brendani have also shown; Ireland, Navigating, 18.

141 On the horrea, Genesis 41: 35-36: "qui jam nunc futuri sunt, congreget in horrea: et omne frumentum sub Pharaonis potestate condatur, serveturque in urbibus et praeparetur futurae septem annorum fami, quae oppressura est Aegyptum, et non consumetur terra inopia«; on Mont Aureus, Itinerary, 20. 


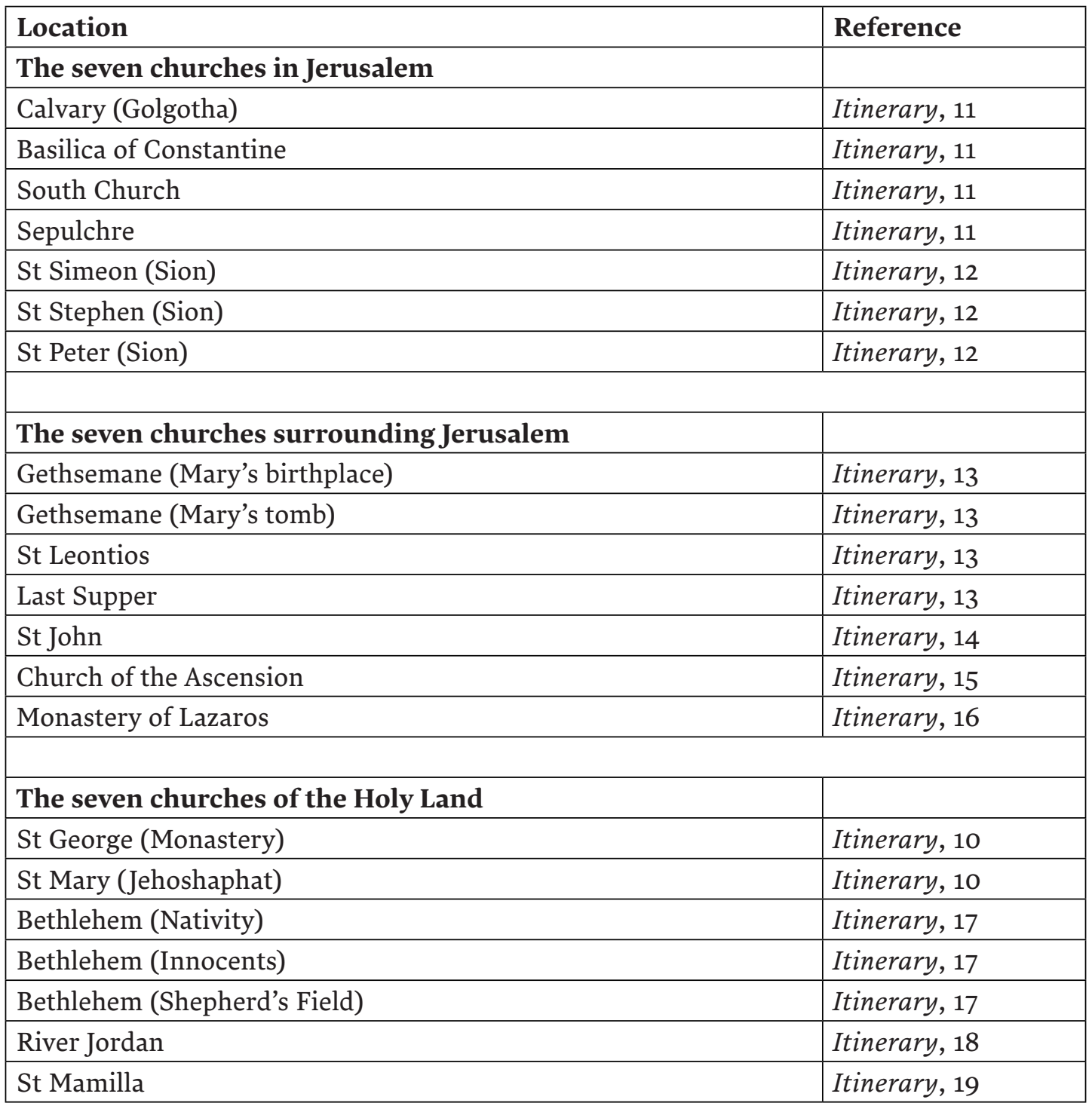

Fig. 2: Churches visited by Bernard in the Holy Land

Bernard's consistent use of the Babylonian "six" and Christian "seven « indicates that these embedded numerical meanings are unlikely to be coincidental and indeed conform to other sections of the Itinerary where the symbolic significance of numbers actively informs his conception of the landscape he describes. As we have seen, Bernard's deliberate modification of Bede's description of the Tomb of Christ probably functioned to stress the role of the Sepulchre as a typological symbol centred upon the revelation of Christ as the Messiah. ${ }^{142}$ With this central cosmic point firmly established, Bernard's journey then proceeds to trace the contours of the landscape that stresses the completeness of divine creation (three rings of seven churches) unveiled through Christian revelation and juxtaposed against the temporality of the earthly "six" of the Abbasid Babylon. 


\section{Angelic Intercessors}

Although we cannot know how receptive Bernard's audience was to these numerological allusions, audiences less familiar with these more complex exegetical themes could encounter more overt symbolic reference to the Itinerary's emphasis on penance and the use of biblical models of time and world kingdoms. Although the Itinerary is not an apocalypse narrative, its topography draws together a number of themes pertinent to an understanding of biblical temporal cycles and the eventual promise of Christian triumph. Among the most explicit of these allusions is the role that angels and angelic revelations perform as a feature of Bernard's experience as he moves across the landscape and observes signs of their intervention in the course of human history. As a further confirmation of Bernard's numerological working, the Itinerary is structured around seven separate episodes of angelic apparition that provoke immediate parallels with the seven angels of the Book of Revelation. ${ }^{143}$

The importance of angels as instruments of divine intercession - as opposed to revelation - is also an innovation of Bernard's Itinerary, which has little precedent in earlier examples of Latin Itineraria. Although Biblical loci associated with angelic visitations are noted by Adomnán's De Locis Sanctis and Hugeberc's Vita Willibali, neither text identifies cases of contemporary angelic intervention. ${ }^{144}$ Within Bernard's Itinerary, however, contemporary angelic visitations are commonplace and serve as a vehicle through which divine will operates within the human world (Fig. 3).

143 Revelation 8. 2.

144 Adomnán', De Locis Sanctis, 2.26.1-5, ed. Bieler, 218-219; Bede, De locis sanctis 15.1-2, ed. Fraipont, 275-276. A further English translation is also available in Wilkinson, Jerusalem Pilgrims, 109. 


\begin{tabular}{|l|l|l|}
\hline \multicolumn{3}{|c|}{ Angelic manifestations in the Itinerary } \\
\hline Location & Event & Reference \\
\hline Monte Gargano & An angel appears to Joseph & Itinerary, 2 \\
\hline Alexandria & An angel releases Christians from prison & Itinerary, 7 \\
\hline Farama & An angel appears to Joseph & Itinerary, 9 \\
\hline Church of the Anastasis & $\begin{array}{l}\text { An angel appears during the miracle of the } \\
\text { Holy Fire. The angel that appeared by the tomb. }\end{array}$ & Itinerary, 11 \\
\hline Holy Sion & An angel releases Peter from prison & Itinerary, 12 \\
\hline Habbukuk's Field & An angel aids Daniel in prison & Itinerary, 17 \\
\hline Shepherd's Fields & Angel appears to the Shepherds & Itinerary, 17 \\
\hline
\end{tabular}

\begin{tabular}{|l|l|l|}
\hline $\begin{array}{l}\text { Sites associated } \\
\text { with angels }\end{array}$ & & \\
\hline Monte Gargano & An angel appears to Joseph & Itinerary, 2 \\
\hline Alexandria & An angel releases Christians from prison & Itinerary, 7 \\
\hline Farama & An angel appears to Joseph & Itinerary, 9 \\
\hline Church of the Anastasis & $\begin{array}{l}\text { An angel appears during the miracle of the } \\
\text { Holy Fire. The angel that appeared by the tomb. }\end{array}$ & Itinerary, 11 \\
\hline Holy Sion & An angel releases Peter from prison & Itinerary, 12 \\
\hline Habbukuk's Field & An angel aids Daniel in prison & Itinerary, 17 \\
\hline Shepherds Fields & Angel appears to the Shepherds & Itinerary, 17 \\
\hline Mont Aureus & Apparition of the Archangel Michael & Itinerary, 20 \\
\hline Mont Sant Michael & Apparition of the Archangel Michael & Itinerary, 22 \\
\hline
\end{tabular}

Fig. 3: Angelic revelations in the Itinerary

That Bernard sought to situate angels within a role that stressed their importance as intercessors, rather than messengers, is demonstrated by the places purportedly visited by Bernard where biblical angelic revelations are said to have occurred. Nazareth, the setting of the Annunciation, for example, which had emerged as a fairly standard marker of western perceptions of the Holy Land by the early eighth century, is missing from Bernard's topography, despite appearing in the earlier text of Bede which Bernard is known to have consulted. ${ }^{145}$ Instead, the Itinerary emphasises places within scripture where divine intervention, rather than revelation, had been administered through the agency of angels.

The Itinerary's conception of angelic intercession can be seen to operate on two temporal levels: angelic revelation of the biblical past and angelic apparition in the ninth-century present. Throughout the Itinerary, Bernard and his companions frequently encounter places that bear witness to past kingdoms whose power had been subverted by angelic agency. Bernard's description of his visit to Farama recalls the angel's warning to Joseph (Matthew 2.13), which preceded the flight of the Holy Family to Egypt. ${ }^{146}$ In Jerusalem, Bernard visits the iron gates

145 Bede, De locis sanctis, 15.1-2, ed. Fraipont, 275-276. English translation in Wilkinson, Jerusalem Pilgrims, 109. It also appears in Adomnán', De Locis Sanctis, 2.26.1-5, ed. Bieler, 218-219.

146 Itinerary, 9. 
through which the angel led Peter from prison (Acts 12: 7-11); the story of Habbukuk's field and assistance to Daniel is another of these angelic revelations that emphasised the futility of earthly rule against divine intervention.

The Itinerary's focus on these particular episodes conforms to a broader understanding of angelic manifestation that evidently drew upon a set of beliefs about angels resonant with the teachings of the De Coelesti Hierarchia attributed to Pseudo-Dionysius as it was understood by ninth-century commentators. Like Eriugena, Bernard's Itinerary distinguishes the apparition of Gabriel at Nazareth from other examples of angelic visitation in which the identities of the angel were unknown. ${ }^{147}$ Instead, the Itinerary places emphasis upon angelic revelations in scripture that related to angelic intercession in times of danger: to the imprisoned Daniel and Peter and to Joseph before the flight to Egypt. ${ }^{148}$

As a counterpart to historical cases of angelic apparition, Bernard's experiences in the Babylon of Egypt provide further confirmation of divine intervention in his own age. Like Daniel in the biblical Babylon, Bernard is arrested and imprisoned for six days. ${ }^{149} \mathrm{Al}-$ though his release is secured through payment of a fine (of an ominous thirteen denarii), he attributes his release to the help of God (cum Dei auxilio). ${ }^{150}$ Elsewhere in the text, God sends angels to release Christians imprisoned by the Muslim authorities. ${ }^{151}$ In identifying the ninthcentury Abbasid Caliphate as another »Babylon«, the Itinerary fashions a structure in which Bernard's journey to Jerusalem is situated within this revelatory cycle as yet another human power chastened by divine will.

Bernard's topography and numbering of angelic revelation further reinforces this underlying temporal model. Of the seven separate angelic appearances, which provoke comparison with the seven angels of Revelation 8:1-2, six are situated in Egypt and the Holy Land, with the final angelic manifestation taking place within the territories of the Christian west in Monte Gargano. ${ }^{152}$ The significance of this becomes more apparent when we consider that of the seven angelic apparitions described by the Itinerary, only one example explicitly identifies the manifest angel as the Archangel Michael, whose appearance is limited to sites within the Christian-held territories of Italy and Normandy.

147 Pseudo-Dionysius Areopagita, De Coelesti Hierarchia, IX, ed. Heil and Ritter, 20-24.

148 Matthew 2:13. Pseudo-Dionysius Areopagita, De Coelesti Hierarchia, 9; Rorem, Eriugena's, 216-219. John Scottus' commentary of the De Coelesti Hierarchia, completed in 862, ascribed the role to Gabriel as the teacher of the mysteries but does not identify Gabriel as the angel who subsequently appeared to Joseph and the Shepherds. For John these later episodes were to be linked to other angels. This draws upon Pseudo-Dionysius Areopagita, De Coelest $i$ Hierarchia, 4 and 9. ed. Heil and Ritter, 20-24, 36-41, trans. Parker, 117-120, 127-128.

149 Acts 12: 7-11.

150 As we have seen, this allusion is lost in the Wilkinson translation where "donec post dies sex inito consilio, cum Dei auxilio, tredecim denarius unusquique dedit pro se, sicut et superius" is rendered as "Then, with the help of God «: Itinerary, 7; Willkinson, Jerusalem Pilgrims (second edition), 263.

151 "Si autem talis est, ut non possit hos XIII denarios solver, sive sit incola, sive advena christianus, mittitur in carcerem, donec aut Dei pietate per angelum suum liberartur, aut ab aliis bonis christianis redimitur", Itinerary 7.

152 Itinerary, 22. 
Sites associated with the Archangel Michael thus form a literary pairing within the Itinerary, as both the first and last holy sites described by Bernard but also the most recent in terms of the text's timeline of angelic intervention..$^{153}$ The first locus of apparition is Monte Gargano, which Bernard visits at the beginning of his journey. Here, Bernard describes how the Archangel Michael appeared and commanded a church to be built in his honour - a legend that can be traced to the sixth century, but had become widely disseminated in several redactions by Bernard's lifetime. ${ }^{154}$ Two further sites connected with Michael are also described in the text, but not explicitly linked with his apparition. Having parted with companions in Rome, Bernard's final stage of the journey brings him to Mont-Saint-Michel where the Itinerary informs the reader of the miracle on the feast of the archangel at which the sea miraculously parts and allows visitors to cross to the island. ${ }^{155} \mathrm{~A}$ further site associated with the cult of Michael, at Mons Aureus (San Michele sul Tusciano in Olevano), is also visited by Bernard and his companions upon their return from Jerusalem. ${ }^{156}$

As has been noted by several earlier studies, Michael's role within the West's broader conception of biblical time was well established at the time of the Itinerary's composition in c. 867 , and drew directly upon biblical precedent where Michael appears as the leader of the heavenly armies at the end of days ${ }^{157}$ Bernard's Itinerary is not explicit about its connection to these sources, although the text's recurrent discussion of the Archangel Michael in conjunction with the themes of Babylon and pericopes that evoke the life of Daniel situate the Itinerary within this broader exegetical current. ${ }^{158}$ By identifying the apparition of the final angel as Michael, the Itinerary also draws directly upon the biblical role of Michael as the defender of Israel who will rise to protect his people..$^{159}$ Bernard's Itinerary effectively offers witness of the final manifestation of that cycle at Monte Gargano and identifies two further sites, at Mont Aureus and Mont Saint-Michel, where the angel Michael was also believed to have appeared. In doing so, the Itinerary situates his descriptions of ninth-century Italy within an established temporal framework in which the Christians of the west are identified as Michael's people and aligned with the broader expectation of Christian triumph. ${ }^{160}$

153 Itinerary, 2, 22.

154 The main study is Arnold, Footprints of Michael the Archangel; Arnold, Arcadia becomes Jerusalem, 567-588; Everett, Liber de Apparitione, 364-391; Callahan, Cult of St. Michael, 181-205.

155 Itinerary, 22. Allen Smith, Angel's power, 347-360; Lelegard, Saint Aubert, 29-52; The oldest extant copy of this text dates from the abbacy of Mainard II (991-1009) and is found in Avranches, Bibliothèque municipale, MS 211, fols. 181-188v. Jonathan J. Alexander identifies the copyist as the monk Hervardus: Alexander, Norman Illumination, Appendix II. The standard edition of the Apparitio differs from this version in its inclusion of twelfth-century additions dealing with donations: Apparitio, ed. Migne.

156 Itinerary, 21. On the shrine, Di Muro et al. La Grotta.

157 Revelation 12:7-9.

158 See also Callahan, Cult of St. Michael the Archangel, 181-205, who discusses the importance of Michael's identity as the angel of the west.

159 Daniel 12.1.

160 On the growing importance of Michael's cult in Francia after the eighth century, including the identification of Michael as the angel of the Franks: Johnson, Saint Michael the Archangel, 43-45. 


\section{World Kingdoms}

This correlation is fully realised by the temporal sequences of rulers and vestiges of earlier human powers that Bernard encounters, all of which evoke the temporal cycle of Old Testament kingdoms noted in the Book of Daniel. Examined in sequence, the Itinerary identifies and names four of these temporal powers: "King Pharaoh" of Egypt in the days of Joseph; "Nebuchadnezzar" of Babylon, in the days of Daniel; Amarmoni, Emperor of the Saracens in the "Babylon" of Bernard's lifetime, and, finally, the Romans, who are described twice in the Itinerary through reference to Charlemagne in Jerusalem and his successors, Louis II, Lothar II and Charles of Provence. ${ }^{161}$ The closing lines of the Itinerary in Chapter 24, which celebrate the peace and order established by Louis II, also suggest that Bernard sought to situate Francia as the latest, and possibly the last, of these temporal powers. ${ }^{162}$

The Itinerary's descriptions of Charlemagne (gloriossissimi imperatoris Karoli) and the vestiges of Frankish intervention in Jerusalem are also framed by several motifs that stress their connection to biblical prophesies. Upon reaching Jerusalem, Bernard and his companions stayed in the hospitium of the "most-glorious emperor Charles", which lies adjacent to a church dedicated to St Mary. ${ }^{163}$

From Emmaus we reached the holy city of Jerusalem and we were received in the hospice of the most glorious emperor Charles and they receive all those who come in the cause of devotion and who speak the Roman language. Beside it is the church in honour of holy Mary and has a splendid library built by the aforementioned emperor; with twelve mansions, fields, vines, and a garden in the valley of Jehoshaphat. In front of the hospice is a market in which everyone who does business there pays the person in charge two aurei every year.

Bernard, Itinerary, 10

Although the location and function of the complex remains a subject of considerable recent debate, the details supplied in Bernard's Itinerary are presented in in such a way as to stress its correlation with eschatological models. The motif of the gathering of lingua loquentes Romana calls to mind the gathering of nations and reign of a wise king of Joel 3.12 and Jeremiah 23.3-6. Charlemagne's endowment of twelve mansions in the Valley of Jehoshaphat further alludes to the return of the twelve tribes of Israel and echoes the significance of the number twelve in the eschatological prophecies of Revelation 21:10-26. Bernard's employment of the word mansionibus to describe the twelve foundations of Charlemagne, notably sits within a much broader exegetical tradition that utilised the term in reference to the tribes of Israel. ${ }^{164}$

161 Itinerary, 10, 24.

162 Itinerary, 24.

163 Itinerary, 10.

164 Key among them is Jerome Epistola, 78, ed. Hilberg, 49-87; Ps.-Ambrose, De XLII mansionibus filiorum Israel, ed. Migne, 9-40; Isidore of Seville, Quaestiones in Numeros, ed. Migne, 339-60; Bede, De mansionibus filiorum Israel, ed. Migne, 699-702. 
That Bernard identified Charlemagne as the "fourth emperor" is difficult to determine from the Itinerary itself, although the text's allusions to these signs and numerical symbols suggests that this is how he broadly conceptualised the role of the Franks as the last of the world kingdoms. All that may be said, very broadly, is that Bernard operated within a wider intellectual context that anticipated the emergence in the west of the final emperor envisioned in Daniel 2 and Daniel 7. ${ }^{165}$

Yet, although evidently shaped by eschatological motifs, the Itinerary is not overtly apocalyptic and does not anticipate the imminent end of days. Instead, by drawing upon the temporal structure of the biblical world kingdoms and laying emphasis on the Beneventan transgression and enslavement, the Itinerary situates the political events of the period 839-c. 867 (which it describes) within a biblical model of transgression, chastisement and redemption. Bernard's emphasis on this model is evident from the intersection between the places he visits and the biblical stories and typologies that were commonly viewed as models of idealised imperial rule and penance by the mid-ninth century, of which the Pericope Adulterae is the most explicit example. Bernard's witness to sites associated with the prophet Daniel, as well as the biblical rulers Nebuchadnezzar and Pharaoh, present other examples widely utilised in ninth-century discussions of ideal rule. ${ }^{166}$ Hrabanus Maurus' commentary on the Book of Daniel offers the clearest example, although its themes and emphasis on an Old Testament scheme of world kingdoms also resonates in the works of Notker the Stammerer and Haimo of Auxerre, both likely active in Bernard's lifetime. ${ }^{167}$

The Itinerary evidently does not set out to establish the criteria and characteristics of ideal political behaviour, although its critique of the Beneventan transgression of Christian law (legem Christianorum), indicates that it generally operates within this moral code. ${ }^{168}$ Instead, Bernard shows through his journey that the biblical stories and revelations so connected with the themes of justice, mercy and righteous rule were indeed true and confirmed by the physical presence of relics and churches that bore witness to these events. In its emphasis on just rule, penitence, and salvation, the Itinerary traces a topography that resonates with the broader exegetical currents of the 860 s and effectively grounds them in topographic reality.

165 The idea is to be encountered most explicitly in the Latin redactions of the seventh-century Syriac Apocalypse of Pseudo Methodius that emerged in the mid-eighth century, in which the original wording of the prophecy referring to the "emperor of the Greeks " was amended to read rex christianorum and reworked to assimilate this identity with a western Christian ruler. Marc Laureys and Daniel Verhelst have identified ninety-one manuscripts of this version (five predating 1100) and forty-four of the original Latin translation (ten predating 1100). See Laureys and Verhelst, Pseudo-Methodius, 112-136; Alexander, Diffusion, 75-76. Copies of the Latin translation were certainly available in the libraries of Corbie and St Gall, and also in San Vincenzo al Volturno, around a century before Bernard wrote, and can be seen to have influenced many of his contemporaries in their own writings throughout the ninth century, See also Alexander, Diffusion, 75-76.

166 For a broader discussion, see De Jong, Empireas ecclesia, 191-226.

167 De Jong, Biblical historia for rulers, 210; Shimahara, Daniel et les visions politiques, 19-32; Palmer, Apocalypse, 165-167; Notker the Stammerer, Gesta Karoli, 1.1, ed. Haefele, 1, trans. Ganz, 55. On Haimo of Auxerre: Savigini, Commentario di Aimone, 207-266; Contreni, By lions, 29-56. As Miriam Czock has observed, ecclesiastical responses to these changes were marked by a growing concern on the question of law and just rule that repeatedly drew upon Old Testament models to regulate high political behaviour in anticipation of the Last Judgment. Czock, Creating, 101-120; Palmer, Apocalypse, 160-161; see also the important study relating to the reign of Louis the Pious, De Jong, Penitential State.

168 Itinerary, 25. 
Central to this interpretation is the redemptive message of the story of the Passion and the Israelite exodus from Egypt as perpetual reminders of God's assistance to the righteous. Bernard's optimistic assessment of the reign of Louis II also accords with this general context and proposes that the Itinerary may be read as a reaction to the challenges that faced the emperor in the late 860s and the victories that awaited him if the Itinerary's messages and signs were heeded. ${ }^{169}$ If Ackermann's dating of Bernard's Itinerary to c. 867 -c. 871 continues to hold weight, this would situate the composition of the Itinerary in the aftermath of Louis II's success against the Arabs in southern Italy and in the short period that anticipated the successful capture of Bari. ${ }^{170}$ Drawing together a physical itinerary that bore witness to biblical stories of loss, penitence, justice and redemption, Bernard's Holy Land situates the fluctuations of the 860s within a timeframe of divine revelation and biblical history that stressed the impermanence of this hardship for God's chosen people. Bernard's attempts to place Monte Gargano within a topography of anticipated Christian triumph during the reign of Louis II also resonate with the concurrent attempts by the emperor to align himself with the shrine through a number of donations and endowments in the same years that the Itinerary was being composed. ${ }^{171}$

Yet just over a decade later, with the death of Louis II in 875 a new political landscape had emerged. ${ }^{172}$ It is likely that Bernard's Itinerary, whose central exegesis was so embedded in an anticipated Christian triumph and high expectation for the reign of Louis, no longer resonated with audiences within this changing context and fell into relative obscurity. In this light, the text's resurgence in the 1120s, at the time of the establishment of the Norman Kingdom of Roger II and the consolidation of Christian power in the Latin Kingdom of Jerusalem, is not likely to be coincidental, but may indicate a new-found interest in the themes that Bernard had articulated three centuries earlier.

There remain, nonetheless, many questions to be answered about the Itinerary and further research will undoubtedly enable us to understand its elusive writer and its specific origins in greater resolution. What this study has aimed to demonstrate, however, is that a more contextual reading of the work with respect to its broader intellectual and exegetical culture, is fundamental to a recognition of the Itinerary as a sophisticated reworking of an established literary genre that had not been widely utilised since Late Antiquity. It also partially rescues Bernard from his anonymity, identifying him as a figure enmeshed in the rhythms and concerns of biblical exegetes at the turn of the mid-ninth century and a writer capable of utilising a (by then) centuries-old literary formula to address specific questions pertinent to his own time. This recognition, nevertheless, comes at a price. The more that the Itinerary is understood in exegetical terms, the more the belief that it can straightforwardly inform our understanding of the intricacies of western travel in the Caliphate and the Carolingian presence within the ninth-century Holy Land will require considered reflection. Yet, in its

\footnotetext{
169 Itinerary, 25.

170 For overviews of the main developments, with further references, see Wickham. Early Medieval Italy, 62-63; Alexander, Byzantine Apocalyptic Tradition, 110-114.

171 See Garipzanov, Symbolic Language, 82-82, with further references.

172 Nelson, Charles the Bald; Goldberg, Struggle for Empire, 304-334.
} 
place, emerges a source that stands to tell us much about how writers in the 860 s conceptualised and interpreted a world in constant change and how they sought to situate the rise of Abbasid power within a temporal and salvific worldview. Rather than what it might tell us about Jerusalem, the Itinerary holds a mirror to how Christians in the west understood their own place within the wider world and their history as God's own people.

\section{Acknowledgements}

This article emerged as part of a wider body of research at the churches of Sant'Ambrogio, Montecorvino Rovella and San Michele sul Tusciano, Olevano, as part of the Crossroads of Empires Project. I thank the British Academy, the Leverhulme Trust and the Gerda Henkel foundation for their generous support of this research. I would also like to thank Henriette van der Blom, Niall Livingstone ( $\dagger$ ), Maeve McHugh and Fiona Mitchell who commented on an earlier draft of this article as part of the Birmingham research reading group. Special thanks also go to Leslie Brubaker, Rebecca Darley, Francesca Dell'Acqua, Caroline Goodson and Chris Wickham for their detailed comments on the article. 


\title{
References
}

\author{
Abbreviations \\ CCCM = Corpus Christianorum Continuatio Mediaevalis \\ CCSL $=$ Corpus Christianorum Series Latina \\ CSEL $=$ Corpus Scriptorum Ecclesiasticorum Latinorum \\ MGH = Monumenta Germaniae Historica \\ PL = Patrologiae Cursus Completus, Series Latina, ed. Jacques-Paul Migne (Paris, 1844- \\ 1890). Adomnán, De Locis Sanctis, ed. Ludwig Bieler, CCSL 175, (Turnhout, 1965) 175-234.
}

\section{Primary Sources}

Alcuin, Commemoratorium in Joannem, PL 100, 743-1008.

Ambrose, Expositio evangelii secundum Lucam, ed. Karl Schenkl, Sancti Ambrosii Opera, pars quarta. Expositio Evangelii Secundum Lucan (Prague, 1902).

Ambrosius Autpertus, Expositio in Apocalypsin, ed. Robert Weber, Ambrose Autperti opera, CCCM 22-27A (Turnhout, 1975), 5-462, 465-872.

Augustine, De adulterinis coniugiis, ed. Joseph Zycha, CSEL 41 (Turnhout, 1900). English translation: Charles Wilcox, Saint Augustine. Treatises on Marriage and Other Subjects (Washington D.C, 1955).

Augustine, De Civitate Dei, ed. Bernhard Dombart and Alfons Kalb, CCSL 47 (Turnhout, 1955).

Augustine, De Doctrina Christiana, ed. Joseph Martin, CCSL 32 (Turnhout, 1962).

Augustine, De Genesi ad litteram libri duodecim, ed. Joseph Zycha, CSEL 28.1 (Vienna, 1894).

Augustine, De trinitate libri, ed. William J. Mountain and Francois Glorie, CCSL 50 (Turnhout, 1968).

Augustine, Epistulae, ed. Alois Goldbacher, CSEL 34 (Vienna, 1898).

Augustine, In Iohannis evangelium tractatus CXXIV, ed. Radbod Willems, CCSL 36 (Turnhout, 1954).

Bede, De Locis Sanctis, ed. Jean Fraipont, CCSL 175 (Turnhout, 1965) 245-28o. English translation: W. Trent Foley and Arthur. G. Holder, Bede. A Biblical Miscellany (Liverpool, 1999) 5-25. English translation: David Hugh Farmer, Ecclesiastical History of the English People. With Bede's Letter to Egbert and Cuthbert's Letter on the Death of Bede (London, 1994).

Bede, De Natura Rerum, ed. Charles W. Jones, CCSL 123A (Turnhout, 1965) 173-234. English translation: Calvin. B. Kendall and Faith Wallis, Bede. On the Nature of Things and on Times (Liverpool, 2010).

Bede, De tabernaculo, ed. David Hurst, CCSL 119 (Turnhout, 1969) 5-139. English translation: Arthur Holder, Bede. On the Tabernacle (Liverpool, 1994).

Bede, De templo Salomonis, ed. David Hurst, CCSL 119 (Turnhout, 1969) 143-234. English translation: Sean Connolly, Bede. On the Temple (Liverpool, 1995).

Bede, De temporum ratione, ed. Charles W. Jones, Bedae opera didascalia 2, CCSL 123B (Turnhout, 1997). English translation: Faith Wallis, Bede. The Reckoning of Time (Liverpool, 1999).

Bede, Expositio in Canticum Abacuc Prophetae, ed. J. E. Hudson CCSL 119B (Turnhout, 1983) 377-409. English translation: Sean Connolly, Bede. On Tobit and on the Canticle of Habakkuk (Dublin, 1997). 
Bede, Historia ecclesiastica gentis Anglorum, ed. and trans. Bertram Colgrave and Roger A. B. Mynors, Bede's Ecclesiastical History of the English People (Oxford, 1969).

Bede, Homelia, ed. David Hurst, CCSL 122 (Turnhout, 1955). English translation: Lawrence T. Martin and David Hurst, Bede the Venerable. Homilies on the Gospels. Book One: Advent to Lent (Kalamazoo, 1991).

Bede, In Actus apostolorum libros, Expositio Actuum Apostolorum, ed. Max Laistner, CCSL 121 (Turnhout, 1983). English translation: Lawrence T. Martin, The Venerable Bede. Commentary on the Acts of the Apostles (Kalamazoo, 1989).

Bede, In Marci evangelium exposition, ed. David Hurst, CCSL 120 (Turnhout, 1960).

Bernard the Monk, Bernardi Itinerarium, PL 121, 569-574.

Bernardi Itinerarium, ed. Titus Tobler, Descriptiones Terrae Sancta Ex Saeculo VII., IX., XII. et $X V$ (Leipzig, 1874) 86-99.

Bernardi monarchi Franci aliud Itinerarium, ed. Johannes Mabillion, Acta sanctorum Ordinis sancti Benedicti, III/2 (Paris, 1672) 523-526.

Cassiodorus, Expositio Psalmorum, ed. Marc Adriaen, CCSL 98 (Turnhout, 1958). English translation: Patrick G. Walsh, Cassiodorus. Explanation of the Psalms: Vol. II, Psalms 51100 (New York, NJ, 1991).

Dhuoda, Liber Manualis, ed. and trans. Marcelle Thiebaux, Dhuoda. Handbook for Her Warrior Son (Cambridge, 1998).

Eclogae de officio missae, PL 105, 1315-1332D.

Erchempertus, Historia Langobardorum Beneventanorum, ed. Georg H. Pertz and Georg Waitz, MGH Scriptores Rerum Langobardicarum et Italicarum saec. VI-IX I (Hannover, 1878).

Gregory of Tours, Libri Historiarum, ed. Bruno Krusch and Wilhelm Levison, MGH Scriptores rerum Merovingicarum I 1 (Hannover, 1951). English translation: Lewis Thorpe, Gregory of Tours. The History of the Franks (London, 1974).

Gregory the Great, Homilia, 26, PL 76, 1200B-1201B, English translation in David Hurst, Gregory the Great, Forty Gospel Homilies (Kalamazoo, 1990).

Gregory, Moralia in Job, ed. Marc Adriaen, CCSL 143B. 3 vols. (Turnout 1979-1985). English translation in John Bliss, Morals on the Books of Job by St. Gregory the Great, 4 vols. (Oxford, 1844-1850).

Haimo of Auxerre, Homiliae de tempore, PL 118, 11-746.

Haimo, Expositio in Apocalypsin, PL 117, 937-1226.

Hilarius of Poitiers, De Trinitate, ed. Pieter Smulders, CCSL 62IA (Turnhout, 1980).

Hippolytus of Rome, In Danielem, ed. and trans. Maurice Lefèvre, Hippolytus. Commentaire sur Daniel, Sources Chrétiennes 14 (Paris, 1947).

Hrabanus Maurus, Allegoriae in sacram Scripturam, PL 112, cols. 884-885.

Hrabanus Maurus, Expositio in Mattaeum, VII (24), ed. Bengt Löfstedt, CCCM 174A (Turnhout, 2000).

Hrabanus Maurus, Expositio in Matthaeum, ed. Bengt Löfstedt, 2 vols. CCCM 174-174A (Turnhout, 2000).

Hrabanus Maurus, Homily, 15 (In coena Domini), PL 110, 30D-33A.

Hrabanus Maurus, Homily, 13 (In feria IV), PL 110, 27B- 29A.

Isidore of Seville, De Ecclesiasticis Officiis, ed. Christopher M. Lawson. Sancti Isidori Episcopi Hispalensis. CCSL 113 (Turnhout, 1989). English translation: Thomas L. Knoebel, Isidore of Seville. De Ecclesiasticis Officiis (New York, 2008). 
Itinerarium Burdigalense, ed. Paul Geyer and Otto Cuntz, CCSL 175 (Turnhout, 1965) 1-26. Jerome, Commentaria in Danielem, PL 25, 491-584.

Jerome, Epistola 108, ed. Isidor Hilberg, CSEL 55 (Vienna, 1996) 306-351.

Jerome, Homiliae, ed. Germain Morin, Bernard Capelle and Jean Fraipont, CCSL 78

(Brepols, 1958). English translation: Marie Liguori Ewald, The Homilies of Saint Jerome (Washington DC, 2001) and Marie Liguori Ewald, Roy J. Deferrari, Ludwig Schopp and Thomas P. Halton, The Homilies, vol. 2 (Homilies 60-96) (Washington, DC, 1966).

Liber comitis, PL 30, 487-532.

Liber de apparitione sancti Michaelis in monte Gargano, ed. Richard Johnson, St. Michael the Archangel in Medieval English Legend (Woodbridge, 2005) 110-115.

Liber de apparitione sancti Michaelis in monte Gargano, PL 96, 1389-1394.

Liber Pontificalis, ed. Louis Duchesne, Liber Pontificalis. Texte, Introduction et Commentaire, 2 vols. (Paris, 1886-1892). English translation: Raymond Davis, The Lives of the NinthCentury Popes (Liber Pontificalis). The Ancient Biographies of Ten Popes from A.D. 817891 (Liverpool, 1995).

Maximus of Turin, Sermon, 21, PL 57, col. 575-576.

Notker the Stammerer, Gesta Karoli, ed. Hans F. Haefele, MHG Scriptores rerum Germanicarum, Nova series 12 (Berlin, 1959). English translation: David Ganz, Two Lives of Charlemagne (London, 2008), 45-116.

Paschasius, De assumptione sanctae Mariae uirginis (vel Epistula beati Hieronymi et ad Paulam et Eustochium de assumptione), ed. Albert Ripberger, CCCM 56C (Turnhout, 1985).

Paul the Deacon, Homilia I, In Assumptione B. Mariae Virginis, PL 95, 1565D-1569D.

Pseudo Dionysius, De Coelesti Hierarchia, ed. Günter Heil and Adolf. Ritter, PseudoDionysius Areopagita. De Coelesti Hierarchia, De Ecclesiastica Hierarchia, De Mystica Theologia, Epistulae (Berlin, 1991) 7-132. English translation: James Parker, Dionysius the Areopagite, Works (London, 1897).

Pseudo-Eucherius, De Situ Hierusolimitanae Urbis, ed. Jean Fraipont, CCSL 175 (Turnhout, 1965) 237-243.

Pseudo Matthew, Libri de nativitate Mariae. Pseudo-Matthaei Evangelium, textus et commentarius, Libellus de nativitate sanctae Mariae, textux et commentaries, ed. Jan Gijsel, Corpus Christianorum Series Apocryphorum 9 (Turnhout, 1997).

Said ibn Batriq, Nazm al-Jawhar, ed. Louis Cheikho, Eutychii Patriarchae Alexandrini Annales, Corpus Scriptorum Christianorum Orientalium 60, t.6, vol. 51, t.7 (Louvain, 1954). Italian translation in Bartolemeo Pirone, Eutichio, Patriarca di Alessandira (87794), Gli Anni (Cairo, 1987).

Sedulius Scottus, ed. Dean Simpson, Collectaneum Miscellaneum, CCCM 67 (Turnhout, 1988).

Smaragadus of St-Mihiel, Homily, 2, PL 110, 163-166.

Theodosius, De Situ Terrae Sanctae, ed. Paul Geyer, CCSL 175 (Turnhout, 1965) 115-125.

William of Malmesbury, Gesta Regum Anglorum, ed. and trans. Roger A. B. Mynors. Oxford Medieval Texts, vol. 1 (Oxford, 1998). 


\section{Secondary Works}

Ackermann, Josef, Das Itinerarium Bernardi Monachi (Hannover, 2010).

Aist, Rodney, The Christian Topography of Early Islamic Jerusalem. The Evidence of Willibald of Eichstätt (700-787 CE) (Turnhout, 2009).

Alexander, Jonathan. J. G., Norman Illumination at Mont Saint-Michel (Oxford, 1970).

Alexander, Paul. J., The Byzantine Apocalyptic Tradition (Berkeley, 1985).

Alexander, Paul. J., The diffusion of Byzantine apocalypses in the medieval West and the beginnings of Joachimism, in: Ann Williams (ed.), Prophecy and Millenarianism. Essays in Honour of Marjorie Reeves (Harlow, 1980) 55-106.

Allen Smith, Katherine, An angel's power in a bishop's body. The making of the cult of Aubert of Avranches at Mont-Saint-Michel, Journal of Medieval History 29 (2003) 347-360.

Amidon, Philip R. The Church History of Rufinus of Aquileia, books 10 and 11 (New York, 1997).

Andrieu, Michel, Les Ordines Romani du Haut Moyen Age, vol. 3: Les Textes (Louvain, 1961). Arnold, John, Arcadia becomes Jerusalem. Angelic caverns and shrine conversion at Monte Gargano, Speculum 75/3 (2000) 567-588.

Arnold, John, The Footprints of Michael the Archangel. The Formation and Diffusion of a Saintly Cult, c. 300-c. 800 (Basingstoke, 2013).

Bagatti, Bellarmino, Michele Piccirillo and Alberto Prodomo, New Discoveries at the Tomb of Virgin Mary in Gethsemane (Jerusalem, 1975).

Beazley, Raymond, The Dawn of Modern Geography (London, 1897).

Becker, Gustav Heinrich, Catalogi bibliothecarum antiqui (Bonn, 1885).

Bernard, John Henry, Library of the Palestine Pilgrims Text Society, vol. 3 (London, 1893).

Bernard, John Henry, Thomas Hayter Lewis and C. W. Wilson, The Churches of Constantine at Jerusalem. Being Translations from Eusebius and the Early Pilgrims (London, 1896).

Berto, Luigi Andrea, Erchempert, a Reluctant Fustigator of His People. History and Ethnic Pride in Southern Italy at the End of the Ninth Century, Mediterranean Studies 20/2 (2012) 147-175.

Berto, Luigi Andrea, Remembering Old and New Rulers. Lombards and Carolingians in Carolingian Italian Memory, The Medieval History Journal 13/1 (2010) 23-53

Bouet, Pierre and Olivier Desbordes, Chroniques latines du Mont Sant-Michel (IXe-XIIe) siècle), Les manuscrits du Mont Sant-Michel (Caen, 2009).

Bouwen, Frans and Claudine Dauphin, La Piscine probatique de Jésus à Saladin. Le Projet Béthesda (1994-2010) (Jerusalem, 2011).

Bowman, Glen, Mapping history's redemption. Eschatology and topography in the Itinerarium Burdigalense, in: Lee Levine (ed.), Jerusalem. Its Sanctity and Centrality to Judaism, Christianity and Islam (New York, 1998) 163-187.

Brown, George Hardin, A Companion to Bede (Woodbridge, 2009).

Bruce, Scott, Cluny and the Muslims of La Garde-Freinet. Hagiography and the Problem of Islam in Medieval Europe (New York, 2015).

Bullough, Donald, Columba, Adomnán and the achievement of Iona, Scottish Historical Review 43 (1964) 111-130.

Bullough, Donald, Roman books and Carolingian renovatio, in: Donald Bullough (ed.) Carolingian Renewal. Sources and Heritage (Manchester, 1992) 23-50.

Cain, Andrew, Jerome's Epitaph on Paula. A Commentary on the Epitaphium Sanctae Paulae (Oxford, 2013). 
Callahan, Daniel, The Cult of St. Michael the Archangel and the Terrors of the Year 1000, in Richard Landes, Andrew Gow, David C. Van Meter (eds.). The Apocalyptic Year 1000. Religious Expectation and Social Change, 950-1050 (Oxford, 2003) 181-205.

Cary, George, The Medieval Alexander, edited by David J. A. Ross (Cambridge, 1956).

Chazelle, Celia, The Crucified God in the Carolingian Era. Theology and Art of Christ's Passion (Cambridge, 2007).

Chazelle, Celia, Exegesis in the ninth-century eucharist controversy, in: Celia Chazelle and Burton Van Name Edwards (eds.), The Study of the Bible in the Carolingian Era (Turnhout Brepols 2003) 167-187.

Citarella, Armand O., The relations of Amalfi with the Arab world before the Crusades, Speculum 42/2 (1967) 299-312.

Contreni, John, By lions, bishops are meant; by wolves, priests. History, exegesis, and the Carolingian Church in Haimo of Auxerre's Commentary on Ezechiel, Francia 29/1 (2002) 29-56.

Contreni, John, The Carolingian Renaissance, in: John Contreni, Carolingian Learning, Masters and Manuscripts (Aldershot, 1992) 59-74.

Contreni, John, The Carolingian Renaissance. Education and literary culture, in: Rosamond McKitterick (ed.), The New Cambridge Medieval History (Cambridge, 1995) 709-757.

Contreni, John, Learning for God. Education in the Carolingian Age, The Journal of Medieval Latin 24 (2014) 122-123.

Copeland, Rita and Ineke Sluiter, Cassiodorus, Expositio Psalmorum, CA. 540, and Institutiones, CA. 562, in: Rita Copeland and Ineke Sluiter (eds.), Medieval Grammar and Rhetoric. Language Arts and Literary Theory, AD 300-1475 (Oxford, 2012) 210-231.

Czock, Miriam, Creating futures through the lens of revelation in the rhetoric of the Carolingian Reform ca. 750 to ca. 900, in: Matthew Gabriele and James T. Palmer (eds.), Apocalypse and Reform from Late Antiquity to the Middle Ages (London, 2018) 101-120.

Darby, Peter, Bede and the End of Time (Farnham, 2012).

De Jong, Mayke, The empire as ecclesia: Hrabanus Maurus and biblical historia for rulers, in Yitzhak Hen and Matthew Innes (eds.), The Uses of the Past in the Early Middle Ages (Cambridge, 2000) 191-226.

De Jong, Mayke, The empire that was always decaying. The Carolingians (800-888), Medieval Worlds 2 (2015) 6-25.

De Jong, Mayke, Old law and new-found power. Hrabanus Maurus and the Old Testament, in: Jan W. Drijvers and Alasdair A. MacDonald (eds.) Centres of Learning. Learning and Location in Pre-Modern Europe and the Near East (Leiden, 1995) 161-176.

De Jong, Mayke, The Penitential State. Authority and Atonement in the Age of Louis the Pious, 814-840 (Cambridge, 2011).

Del Giacco, Eric, Exegesis and sermon. A comparison of Bede's commentary and homilies on Luke, Medieval Sermon Studies 50/1 (2006) 9-29.

Delaporte, Marianne M., He darkens me with brightness. The theology of Pseudo-Dionysius in Hilduin's Vita of Saint Denis, Religion and Theology 13 (2006) 219-246.

Deluz, Christiane, Itineraire de Bernard, moine franc, in: Danielle Regnier-Bohler (ed.), Croisades et pelegrinages (Paris, 1997) 919-927.

Di Muro, Alessandro, Vittorio Di Cunzolo, Francesco La Manna and Marianna Mastrangelo (eds.), La Grotta di San Michele ad Olevano sul Tusciano. Storia, archeologia e arte di un santuario altomedievale (Olevano sul Tusciano, 2011). 
Dielbold, William J., Verbal, visual, and cultural literacy in medieval art. Word and image in the Psalter of Charles the Bald, Word \& Image. A Journal of Verbal/Visual Enquiry 8/2 (1992) 89-99.

Dutton, Paul Edward, Carolingian Civilization. A Reader (second edition), (Plymouth, 2004).

Elsner, Jas, The Itinerarium Burdigalense. Politics and salvation in the geography of Constantine's empire, The Journal of Roman Studies 90 (2000)181-195.

Etaix, Raymond, L'homéliaire composé par Raban Maur pour l'empereur Lothaire, Recherches augustiniennes 19 (1984) 211-240.

Everett, Nicholas, The Liber de Apparitione S. Michaelis in Monte Gargano and the hagiography of dispossession, Analecta Bollandiana 120 (2002) 364-391.

Ferrari, Michele Camillo, Il »liber Sanctae Crucis" Di Rabano Mauro. Testo - Immagine Contesto (Bern, 1999).

Flint, Valerie, Susanna and the Lothar Crystal. A liturgical perspective, Early Medieval Europe 4/1 (1995) 61-86.

Forrai, Réka, The Notes of Anastasius on Eriugena's Translation of the "Corpus Dionysiacum«, The Journal of Medieval Latin 18 (2008) 74-100.

Frere, Walter H., Studies in the Early Roman Liturgy I. The Kalendar (London, 1934).

Frere, Walter H., Studies in the Early Roman Liturgy II. The Roman Liturgy (London, 1934).

Frere, Walter H., Studies in the Early Roman Liturgy III. The Roman Epistle-Lectionary (London, 1934).

Fulton, Rachel, Mimetic devotion, Marian exegesis, and the historical sense of the Song of Songs, Viator 27 (1996) 85-116.

Gabrieli, Francesco and Umberto Scerrato, Gli Arabi in Italia. Cultura, Contatti E Tradizioni (Milano, 1985).

Garipzanov, Ildar H., Graphic Signs of Authority in Late Antiquity and the Early Middle Ages, 300-900 (Oxford, 2018).

Garipzanov, Ildar H., The Symbolic Language of Authority in the Carolingian World (c. 751-877) (Leiden, 2008).

Gillis, Matthew Bryan, Heresy and Dissent in the Carolingian Empire. The Case of Gottschalk of Orbais (Oxford, 2017).

Godman, Peter, Poets and emperors. Frankish politics and Carolingian poetry (Oxford, 1987).

Goldberg, Eric J., Struggle for Empire. Kingship and Conflict Under Louis the German, 817-876 (New York, 2006).

Gunderson, Lloyd, Alexander's Letter to Aristotle about India (Hain, 1980).

Halevi, Leor, Bernard, explorer of the Muslim Lake. A pilgrimage from Rome to Jerusalem, 867, Medieval Encounters 4/1 (1998) 24-50.

Halporn, James, The manuscripts of Cassiodorus' »Expositio Psalmorum«, Traditio 37 (1981) 388-396.

Hiley, David, Western Plainchant. A Handbook (Oxford, 1993).

Hornby, Emma and Rebecca Maloy, Music and Meaning in Old Hispanic Lenten Chants. Psalmi, Threni and the Easter Vigil Canticles (Woodbridge, 2013) 244-302.

Hoyland, Robert and Sarah Waidler, Adomnán's De Locis Sanctis and the seventh-century Near East, The English Historical Review 129 (2014) 787-807.

Ireland, Darcy E., Navigating the Use of Biblical Numerology in Nauigatio Sancti Brendani. Unpublished MA Thesis (Providence College, 2015). 
Kark, Ruth and Seth Frantzman, The Protestant Garden Tomb in Jerusalem, Englishwomen, and a land transaction in Late Ottoman Palestine, Palestine Exploration Quarterly 142/3 (2010) 199-216.

Khalaf, Omar, The Old English Alexander's letter to Aristotle. Monsters and hybris in the service of exemplarity, English Studies 94/6 (2013) 659-667.

Knust, Jennifer, Early Christian re-writing and the history of the Pericope Adulterae, Journal of Early Christian Studies 14/4 (2006) 485-536.

Knust, Jennifer and Tommy Wasserman, To Cast the First Stone. The transmission of a Gospel story (Princeton and Oxford, 2019).

Kochav, Sarah, The search for a Protestant holy sepulchre. The Garden Tomb in nineteenth-century Jerusalem, Journal of Ecclesiastical history 46/2 (1995) 278-301.

Kornbluth, Genevra, Engraved Gems of the Carolingian Empire (University Park, PA, 1995).

Kornbluth, Genevra, The Susanna Crystal of Lothar II: Chastity, the church, and royal justice, Gesta 31/1 (1992) 25-39.

Kortekaas, George A. A., The transmission of the text of Pseudo-Methodius in Cod. Paris lat. 13348, Revue d'histoire des textes 18 (1988) 63-79.

Kreutz, Barbara, Before the Normans. Southern Italy in the Ninth and Tenth Centuries (Philadelphia, 2011).

Laistner, Max Ludwig Wolfram, A Hand-list of Bede Manuscripts (Ithaca, NY, 1943).

Lambot, Cyrille, L'homelie du Pseudo-Jerome sur L'Assomption et l'Evangile de la Nativité de Marie d'apres une lettre inédite d'Hincmar, Revue Benédictine 46 (1934) 265-282.

Lamoreaux, John, David of Damascus, in: David Thomas and Alexander Mallett (eds.), Christian-Muslim Relations. A Bibliographical History 900-1050 (Leiden, 2010) 79-82.

Lapidge, Michael, The Anglo-Saxon Library (Oxford, 2006).

Laureys, Marc and Daniel Verhelst, Pseudo-Methodius, Revelationes. Textgeschichte und kritische Edition. Ein Leuven-Groninger Forschungsprojekt, in: Werner Verbeke, Daniel Verhelst and Andries Welkenhuysen (eds.), The Use and Abuse of Eschatology in the Middle Ages (Leuven, 1988) 112-136.

Le Goff, Jacques, Time, Work, and Culture in the Middle Ages (Chicago, 1980).

Levinson, Wilhelm, England and the Continent in the Eighth Century (Oxford, 1949).

Leyser, Conrad, From maternal kin to Jesus as mother. Royal genealogy and Marian devotion in the ninth-century west, in: Conrad Leyser and Lesley Smith (eds.), Motherhood, Religion, and Society in Medieval Europe, 400-140o. Essays Presented to Henrietta Leyser (London, 2011) 21-39.

Leyser, Conrad, The memory of Gregory the Great and the making of Latin Europe, 6001000, in: Kate Cooper and Conrad Leyser (eds.), Making Early Medieval Societies. Conflict and Belonging in the Latin West, 300-1200 (Cambridge, 2016) 181-201.

Lifshitz, Felice, Religious Women in Early Carolingian Francia. A Study of Manuscript Transmission and Monastic Culture (Bronx, NY, 2014).

Loew, Elias Avery, The date of the Codex Rehdigeranus, The Journal of Theological Studies 1 (1913) 569-570.

MacLean, Simon, Kingship and Politics in the Late Ninth Century. Charles the Fat and the End of the Carolingian Empire (Cambridge, 2003).

MacLean, Simon, Legislation and politics in late Carolingian Italy. The Ravenna constitutions, Early Medieval Europe 18 (2010) 394-416.

Matis, Hannah, The seclusion of Eustochium. Paschasius Radbertus and the nuns of Soissons, Church History 85/4 (2016) 665-689. 
Mayr-Harting, Henry, Ottonian Book Illumination. An Historical Study (Turnhout, 1991).

McCormick, Michael, Charlemagne's Survey of the Holy Land. Wealth, Personnel, and Buildings of a Mediterranean Church between Antiquity and the Middle Ages (Washington, DC., 2011).

McCormick, Michael, New light on the "Dark Ages«. How the slave trade fuelled the Carolingian economy, Past and Present 177/1, 1 (2002) 17-54.

McCormick, Michael, Origins of the European Economy. Communications and Commerce AD 300-900 (Cambridge, 2002).

McKitterick, Rosamond, Books, Scribes and Learning in the Frankish Kingdoms, Sixth to Ninth Centuries (Aldershot, 1994).

McKitterick, Rosamond, The Carolingians and the Written Word (Cambridge, 1989).

McKitterick, Rosamond, History and Memory in the Carolingian World (Cambridge, 2004).

Metcalfe, Alex, The Muslims of Medieval Italy (Edinburgh, 2009).

Moore, Kathryn, The Architecture of the Christian Holy Land. Reception from Late Antiquity through the Renaissance (Cambridge, 2017).

Moscrop, John James, Measuring Jerusalem. The Palestine Exploration Fund and British Interests in the Holy Land (New York, 2000).

Nelson, Janet L., Charles the Bald (London, 1992).

Nelson, Janet. L., Kingship, law and liturgy in the political thought of Hincmar of Rheims, in: Janet L. Nelson (ed.), Politics and Ritual in Early Medieval Europe (London, 1986).

Nelson, Janet L., Literacy in Carolingian government, in Rosamond McKitterick (ed.), The Uses of Literacy in Early Mediaeval Europe (Cambridge, 1990).

Noble, Thomas F. X., Literacy and the papal government in Late Antiquity and the Early Middle Ages, in: Rosamond McKitterick (ed.), The Uses of Literacy in Early Mediaeval Europe (Cambridge, 1992) 8-133.

Norwood, Frederick, The political pretensions of Pope Nicholas I, Church History 15/4 (1946) 271-285.

O'Loughlin, Thomas, Adomnán and Arculf. The case of an expert witness, Journal of Medieval Latin 7 (1997) 127-146.O'Loughlin, Thomas, The De locis sanctis as a liturgical text, in: Jonathan M. Wooding, Rodney Aist, Thomas O. Clancy and Thomas O'Loughlin (eds.), Adomnán of Iona. Theologian, Lawmaker, Peacemaker (Dublin, 2010) 181-192.

O'Loughlin, Thomas, The exegetical purpose of Adomnán's "De Locis Sanctis", Cambridge Medieval Celtic Studies 24 (1992) 37-53.

O'Loughlin, Thomas, The Library of Iona in the late seventh century. The evidence from Adomnán's De locis sanctis, Ériu 45 (1994) 33-52.

O'Loughlin, Thomas, The symbol gives life. Eucherius of Lyons' Formula for Exegesis, in: Thomas Finan and Vincent Twomey (eds.), Scriptural Interpretation in the Fathers. Letter and Spirit (Dublin, 1995), 221-252.

Palmer, James, The Apocalypse in the Early Middle Ages (Cambridge, 2014).

Palmer, James T., The ends and futures of Bede's "De temporum ratione», in: Faith Wallis and Peter Darby (eds.), Bede and the Future (Aldershot, 2014).

Richardson, Nicholas J., Prudentius' Hymns for Hours and Seasons. Liber Cathemerinon. (London, 2016).

Rorem, Paul, The early Latin Dionysius. Eriugena and Hugh of St. Victor, Modern Theology 24/4 (2008) 601-614.

Rorem, Paul, Eriugena's Commentary on the Dionysian Celestial Hierarchy (Toronto, 2005). 
Ross, David John Athole, A check-list of Mss of three Alexander texts. The Julius Valerius "Epitome", the "Epistola ad Aristotelem" and the "Collatio cum Dindimo", Scriptorium 10 (1956) 127-132.

Salway, Benet, Sea and river travel in the Roman itinerary literature, in: Kai Brodersen and Richard Talbert (eds.), Space in the Roman World. Its Perception and Presentation (Münster, 2004) 43-96.

Salway, Benet, Travel, Itineraria and Tabellaria, in: Colin Adams and Ray Laurence (eds.) Travel and Geography in the Roman Empire (London, 2001) 22-66.

Savigini, Raffaele, Il commentario di Aimone all'appocalisse, in: Rossana E. Guglielmetti (ed.), L'Apocalisse nel Medievo (Florence, 2011) 207-266.

Saxon, Elizabeth, The Eucharist in Romanesque France. Iconography and Theology (Woodbridge, 2006).

Schick, Robert, The Christian Communities of Palestine from Byzantine to Islamic Rule. A Historical and Archaeological Study, Studies in Late Antiquity and Early Islam (Princeton, N.J, 1995).

Schutz, Herbert, The Carolingians in Central Europe, Their History, Arts and Architecture. A Cultural History of Central Europe, 750-900, Cultures, Beliefs and Traditions. Medieval and Early Modern Peoples 18 (Leiden, 2004).

Shalev-Hurvitz, Vered, Holy Sites Encircled. The Early Byzantine Concentric Churches of Jerusalem (Oxford, 2015).

Shimahara, Sumi, Daniel et les visions politiques à l'époque carolingienne, Médiévales 55/2 (2008) 19-32.

Stratmann, Martina, Hinkmar von Reims als Verwalter von Bistum und Kirchenprovinz (Sigmaringen, 1991).

Surles, Robert, Medieval Numerology. A Book of Essays (New York, 1993).

Tkacz, Catherine, Susanna as a type of Christ, Studies in Iconography 20 (1999) 101-153.

Tobler, Titus, Descriptiones Terrae Sancta Ex Saeculo VII., IX., XII. Et XV (Leipzig, 1874).

Vescovi, Michele Luigi, An eschatological mirror. The Romanesque portal of Beaulieu-surDordogne, Gesta 56/1 (2017) 53-80.

Vincent, Louis-Hugues, L’église de l'Éléona, Revue Biblique 8 (1911) 219-265.

Vogels, Heinrich Joseph, Codex Rehdigeranus (Rome, 1913).

Wallis, Faith, "Number Mystique« in early medieval computus texts, in: Teun Koetsier and Luc Bergmans (eds.), Mathematics and the Divine. A Historical Study (Amsterdam, 2005) 181-199.

Webb, Jon R., »Knowledge will be manifold«. Daniel 12.4 and the idea of intellectual progress in the Middle Ages, Speculum 89/2 (2014) 307-357.

Wickham, Chris, Early Medieval Italy. Central Power and Local Society 400-100o (Ann Arbor, 1989).

Wilkinson, John, Jerusalem Pilgrims before the Crusades (Warminster, 1977).

Wilkinson, John, Jerusalem Pilgrims before the Crusades (second edition) (Warminster, 2002).

Woods, David, Arculf's luggage. The sources for Adomnán's "De Locis Sanctis", Ériu 52 (2002) 25-52.

Wright, Thomas, Early Travels in Palestine. Comprising the Narratives of Arculf, Willibald, Bernard, Saewulf, Sigurd, Benjamin of Tudela, Sir John Maundeville, De La Brocquière, and Maundrell (London, 1848).

Zier, Mark A., The medieval Latin interpretation of Daniel. Antecedents to Andrew of St. Victor, Recherches de theologie ancienne et medievale 58 (1991) 43-78. 


\section{List of Figures}

Fig. 1. The five civitates of the Itinerary

Fig. 2. Churches visited by Bernard in the Holy Land

Fig. 3. Angelic revelations in the Itinerary 